\title{
Revisiting the subalpine Mesolithic site Ullafelsen in the Fotsch Valley, Stubai Alps, Austria - new insights into pedogenesis and landscape evolution from leaf-wax-derived $n$-alkanes, black carbon and radiocarbon dating
}

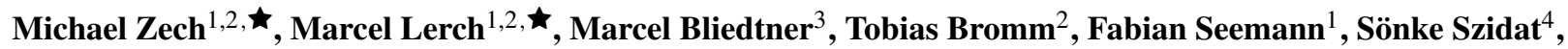 \\ Gary Salazar $^{4}$, Roland Zech ${ }^{3}$, Bruno Glaser ${ }^{2}$, Jean Nicolas Haas ${ }^{5}$, Dieter Schäfer ${ }^{6}$, and Clemens Geitner ${ }^{7}$ \\ ${ }^{1}$ Heisenberg Chair of Physical Geography with Focus on Paleoenvironmental Research, Department of Geosciences, \\ Technische Universität Dresden, Helmholtzstr. 10, 01096 Dresden, Germany \\ ${ }^{2}$ Soil Biogeochemistry Group, Institute of Agronomy and Nutritional Sciences, Martin-Luther University Halle-Wittenberg, \\ Von-Seckendorff-Platz 3, 06120, Halle (Saale), Germany \\ ${ }^{3}$ Chair of Physical Geography, Institute of Geography, Friedrich Schiller University of Jena, \\ Löbdergraben 32, 07743 Jena, Germany \\ ${ }^{4}$ Department of Chemistry, Biochemistry and Pharmaceutical Sciences \& Oeschger Centre for Climate Change Research, \\ University of Bern, Freiestrasse 3, 3012 Bern, Switzerland \\ ${ }^{5}$ Institute of Botany, University of Innsbruck, Sternwartestr. 15, 6020 Innsbruck, Austria \\ ${ }^{6}$ Institute of Archaeology, University of Innsbruck, Langer Weg 11/3, 6020 Innsbruck, Austria \\ ${ }^{7}$ Institute of Geography, University of Innsbruck, Innrain 52, 6020 Innsbruck, Austria \\ ฟThese authors contributed equally to this work.
}

Correspondence: $\quad$ Michael Zech (michael.zech@tu-dresden.de)

Relevant dates: $\quad$ Received: 11 January 2021 - Revised: 29 May 2021 - Accepted: 16 June 2021 Published: 13 July 2021

How to cite:

Zech, M., Lerch, M., Bliedtner, M., Bromm, T., Seemann, F., Szidat, S., Salazar, G., Zech, R., Glaser, B., Haas, J. N., Schäfer, D., and Geitner, C.: Revisiting the subalpine Mesolithic site Ullafelsen in the Fotsch Valley, Stubai Alps, Austria - new insights into pedogenesis and landscape evolution from leafwax-derived $n$-alkanes, black carbon and radiocarbon dating, E\&G Quaternary Sci. J., 70, 171-186, https://doi.org/10.5194/egqsj-70-171-2021, 2021.

Abstract:

Archaeological research in high mountain regions has gotten a lot more attention since the discovery of the copper age mummy called "Ötzi" in the Ötztaler Alps in 1991. In the Tyrolean Stubai Alps, the Mesolithic site Ullafelsen at $1869 \mathrm{~m}$ a.s.l. (above sea level) close to the recent upper timberline in the Fotsch Valley represents, on the one hand, a very important archaeological reference site and offers, on the other hand, intriguing research questions related to, amongst others, pedogenesis. Given that no biomarkers and stable isotopes have been hitherto investigated, we aimed at contributing with respective analyses and additional radiocarbon dating to a better understanding of the landscape evolution and pedogenesis on and around the Ullafelsen.

Our results for modern vegetation suggest that leaf-wax-derived $n$-alkanes allow us to chemotaxonomically distinguish between subalpine deciduous trees $\left(n \mathrm{C}_{27}\right.$ predominance) versus (sub)alpine grasses, herbs and dwarf shrubs $\left(n \mathrm{C}_{29}, n \mathrm{C}_{31}\right.$ and/or $n \mathrm{C}_{33}$ predominance). Except for Juniperus, 
conifers produce no or extremely low $n$-alkane contents. Although no clear vegetation changes could be inferred from the $n$-alkane patterns of the investigated soil profiles, the total $n$-alkane content (TAC) was developed for the first time as an unambiguous proxy for distinguishing between buried (= fossil) topsoils (2Ahb horizons) and humus-enriched subsoils such as Bh horizons of podzols. Based on this leaf wax proxy, we can rule out that the $2 \mathrm{Ahb}$ ?/Bh? horizons under question on the Ullafelsen are buried topsoils as suggested previously. Dating of the $\mathrm{H}_{2} \mathrm{O}_{2}$-pretreated soil samples yielded ${ }^{14} \mathrm{C}$ ages for the podzol Bh horizons ranging from 6.7 to $5.4 \mathrm{cal} \mathrm{kyr} \mathrm{BP}$. This is clearly younger than the overlying Mesolithic living floor (LL) (10.9 to $9.5 \mathrm{cal} \mathrm{kyr}$ BP) but pre-dates the assumed intensification of alpine pasturing from the Bronze Age onwards. Both the LL and the directly overlying OAh3 horizon yielded black carbon maxima and benzene polycarboxylic acid patterns reflecting fireinduced human impact during the Mesolithic. The discrepancy between the Mesolithic charcoal ${ }^{14} \mathrm{C}$ ages (ages of $\geq 9.5 \mathrm{cal} \mathrm{kyr} \mathrm{BP}$ ) versus the ${ }^{14} \mathrm{C}$ ages obtained for bulk $n$-alkanes ranging from 8.2 to 4.9 cal kyr BP suggests that non-alkane-producing conifers predominated the vegetation on and around the Ullafelsen after the Mesolithic occupation. Only with the anthropo-zoological lowering of the timberline associated with alpine pasturing since the Neolithic and especially the Bronze Age has an $n$-alkane-producing vegetation cover (grasses, herbs or dwarf shrubs) started to predominate.

Kurzfassung:

Mit dem Fund der kupferzeitlichen Mumie „Ötzi“ in den Ötztaler Alpen im Jahr 1991 hat die Hochgebirgsarchäologie viel Aufmerksamkeit erfahren. So wurde unter anderem der fürs Mesolithikum sehr bedeutende Fundplatz Ullafelsen in $1869 \mathrm{~m}$ ü.NN. nahe der oberen Waldgrenze im Fotschertal in den Stubaier Alpen entdeckt, der auch aus bodengenetischer Sicht spannende Fragen aufwirft. Ziel der vorliegenden Arbeit ist es, basierend auf Biomarker- und Stabilisotopenanalysen sowie zusätzlichen Radiokohlenstoffdatierungen $\left({ }^{14} \mathrm{C}\right)$ einen Beitrag zum besseren Verständnis der Landschaftsentwicklung und Bodengenese des Untersuchungsgebietes zu leisten.

Unsere Ergebnisse zeigen, dass blattwachsbürtige $n$-Alkane als Lipidbiomarker eine chemotaxonomische Unterscheidung von subalpinen Laubbäumen (Dominanz von $n \mathrm{C}_{27}$ ) und (sub)alpinen Gräsern, Kräutern und Sträuchern (Dominanz von $n \mathrm{C}_{29}, n \mathrm{C}_{31}$ und/oder $n \mathrm{C}_{33}$ ) erlauben. Dagegen produzieren Nadelbäume mit Ausnahme von Juniperus keine oder kaum $n$-Alkane. Zwar lassen sich basierend auf den $n$-Alkanmustern keine eindeutigen Vegetationsänderungen für die untersuchten Bodenprofile vom Ullafelsen belegen; dafür konnten die $n$-Alkangehalte (TAC) erstmalig als aussagekräftiger Proxy für die Unterscheidung von begrabenen ehemaligen (= fossilen) Oberböden (2Ahb Horizonte) und humusangereicherten Unterböden (wie Bh Horizonten von Podsolen) entwickelt werden. Basierend auf diesem Blattwachsproxy kann für die fraglichen 2Ahb?/Bh? Horizonte am Ullafelsen zweifelsfrei ausgeschlossen werden, dass es sich so wie bisher vermutet um begrabene spätglaziale Oberböden handelt. Die Datierung $\mathrm{H}_{2} \mathrm{O}_{2}$-behandelter Bodenproben dieser podsolbürtigen $\mathrm{Bh}$ Horizonte lieferte ${ }^{14} \mathrm{C}$-Alter zwischen 6.7 bis 5.4 cal kyr BP. Das ist stratigraphisch inkonsistent und deutlich jünger als der überlagernde und anhand von Holzkohlen auf 10.9 bis 9.5 cal kyr BP datierte mesolithische Begehungshorizont (LL) aber älter als die ab der Bronzezeit einsetzende Almwirtschaft. Sowohl Black Carbon (BC) Maxima als auch die Muster von Benzolpolycarbonsäuren (BPCAs) als BC Biomarker in der LL und dem unmittelbar überlagernden OAh3 Horizont belegen den menschlichen Einfluss durch Feuer während des Mesolithikums. Während die mesolithischen Holzkohlen ${ }^{14} \mathrm{C}$ Alter $\geq 9.5 \mathrm{cal} \mathrm{kyr} \mathrm{BP}$ liefern, deuten die ${ }^{14} \mathrm{C}$ Alter von 8.2 bis $4.9 \mathrm{cal}$ kyr BP für $n$-Alkane darauf hin, dass unmittelbar nach der mesolithischen Besiedelung am Ullafelsen eine Vegetation vorgeherrscht haben muss, die kaum $n$-Alkane produziert hat (= Nadelbäume). Erst mit der anthropozoologisch bedingten Absenkung der Waldgrenze durch Almwirtschaft seit dem Neolithikum und insbesondere während der Bronzezeit begann $n$-alkanproduzierende Vegetation (Gräser, Kräuter und Zwergsträucher) vorzuherrschen. 


\section{Introduction}

Archaeological research in high mountain regions has gotten a lot of attention since the discovery of the copper age mummy called "Ötzi" in the Ötztaler Alps in 1991. Results of former archaeological research projects show that Mesolithic hunter-gatherers lived in the Alpine regions from the beginning of the Holocene (Fontana et al., 2016, and publications in the special issue MesoLife). For instance, Cornelissen and Reitmaier (2016) presented detailed respective evidence from the central and southeastern Swiss Alps. In the Tyrolean Stubai Alps, the Mesolithic site Ullafelsen at 1869 ma.s.l. (above sea level) and its surroundings in the Fotsch Valley represent a very important archaeological reference site (Schäfer, 2011a) (Fig. 1). Thousands of archaeological artefacts and several fire places were found, which provide evidence of the presence and the human-environment interaction of our ancestors (Schäfer, 2011b). Accordingly, the U1lafelsen was used as a summer camp during the Preboreal and the Boreal from around 10.9 to $9.5 \mathrm{kyr}$ BP. Apart from high mountain archaeology, the "Mesolithic project Ullafelsen" included many more scientific disciplines, ranging from geology, petrography, geomorphology, sedimentology and soil science to (paleo)botany (Schäfer, 2011a).

From a pedological and sedimentological perspective, a striking and frequently occurring light layer (LL) attracted much attention on the Ullafelsen (Geitner et al., 2011, 2014). In the subalpine zone, light horizons typically developed as eluvial albic horizons ( $E$ horizons) due to biotic and climatic factors favouring podzolisation (Zech and Wilke, 1977; Egli et al., 2008). On the Ullafelsen, the LL reveals, however, several characteristics that are untypical for $E$ horizons, and the LL is considered as the Mesolithic living floor. Indeed, most of the artefacts and fire places were found in and on the LL (Fig. 2). Based on stratigraphical features and related soil analyses, Geitner et al. $(2011,2014)$ suggested that the LL developed by aeolian dust deposition during the Younger Dryas (YD) and that it overlies a late glacial buried topsoil (2Ahb) that developed during the favourable climatic conditions of the Bølling-Allerød period. Unequivocal evidence for the existence of this late glacial 2Ahb horizon is, however, hitherto missing, and neither micromorphological nor preliminary ${ }^{13} \mathrm{C}$ nuclear magnetic spectroscopy results were able to resolve this issue.

Over the past decades, analytical progress has allowed us to develop new methods in the field of biogeosciences based on the investigation of organic marker molecules (biomarkers) and stable isotopes (e.g. Glaser, 2005; Zech et al., 2011b), which complements more traditional analytical approaches. For instance, black carbon (BC) based on the analyses of benzene polycarboxylic acids (BPCAs) as organic marker molecules can serve as a proxy for firederived carbon and aromatic-structured molecules in general even if char particles are not preserved (Glaser et al., 1998, 2001; Glaser and Birk, 2012; Lehndorff et al.,
2015). Similarly, plant leaf-wax-derived $n$-alkane biomarkers are preserved in soils and sediments over at least glacialinterglacial timescales, have potential in chemotaxonomic studies and thus allow us to reconstruct vegetation changes from palaeoenvironmental archives even if the preservation of pollen is poor (Zech et al., 2012; Lemma et al., 2019; Trigui et al., 2019). Moreover, compound-class radiocarbon dating of bulk $n$-alkanes was developed during the last years and allows us to address both potential pre-ageing and potential post-depositional rejuvenation of $n$-alkanes in sedimentary archives (Zech et al., 2017; Lerch et al., 2018; Bliedtner et al., 2020). Last but not least, other molecular lipid biomarkers allow us to infer, for instance, dietary information in geoarchaeological studies (Grillo et al., 2020), and the stable nitrogen isotopic composition $\left(\delta^{15} \mathrm{~N}\right)$ of soils allows us to infer the human-induced opening of the $\mathrm{N}$ cycle (Zech et al., 2011a). Such biomarker and stable isotope studies had been hitherto not tested and applied within the "Mesolithic project Ullafelsen".

The overall aim of this geoarchaeological follow-up study was, therefore, to contribute particularly with biomarker and stable isotope analyses, as well as with radiocarbon dating, for a better understanding of the pedogenesis, the human impact and the landscape evolution on and around the Mesolithic site Ullafelsen. More specifically, we addressed the following questions. (i) Is the humus-enriched subsoil horizon on the Ullafelsen a buried topsoil (2Ahb horizon) or humus-enriched by podzolisation (Bh horizon)? (ii) Do biomarker and stable isotope results validate the LL as the Mesolithic living floor and/or eluvial albic horizon? (iii) Do $n$-alkane biomarkers allow us to chemotaxonomically distinguish the dominant vegetation types around the Ullafelsen and is there any evidence for late glacial and Holocene vegetation changes from $n$-alkanes on the Ullafelsen? (iv) Is there evidence for human impact from black carbon on the Ullafelsen? (v) Can we gain new insights from merging existing knowledge with new biomarker-based findings?

\section{Material and methods}

\subsection{Study area: the Ullafelsen in the Fotsch Valley, Stubai Alps, Austria}

The study area was described in detail previously (Schäfer, 2011a). In brief, the approximately $13 \mathrm{~km}$ long Fotsch Valley is situated in the northern part of the Stubai Alps southwest of Innsbruck (Fig. 1). In the south, the highest mountain is the Hohe Villerspitze at $3087 \mathrm{~m}$ a.s.l.; in the north, the Fotsch Creek discharges into the Melach River (tributary of the Inn River) in the Sellrain Valley and the village of Sellrain at about $900 \mathrm{~m}$ a.s.l.

Geologically, the Fotsch Valley is part of the "ÖtztalStubai crystalline complex", which belongs to the Austroalpine nappes. Its metamorphic rocks, which are mainly Para- and Orthogneisses, primarily built up the valley. In 
(a)

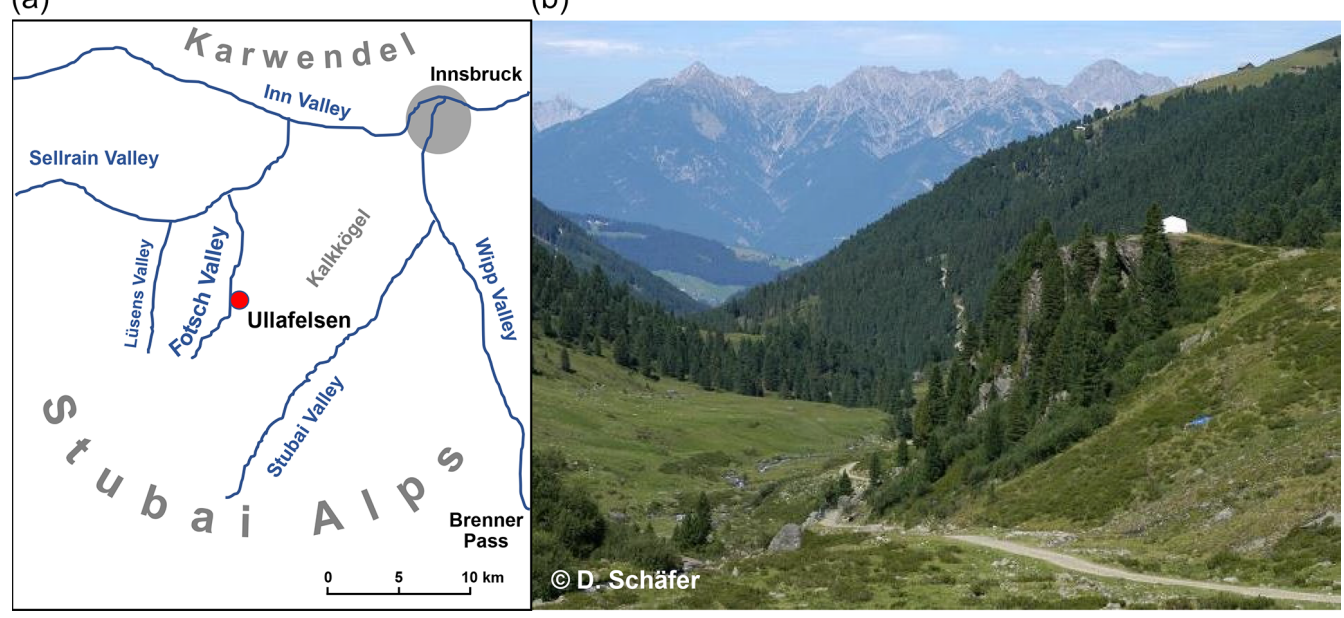

Figure 1. (a) Map showing the location of the Mesolithic site Ullafelsen in the Fotsch Valley southwest of Innsbruck, Austria. (b) Northward view from the inner Fotsch Valley over the Ullafelsen (1869 m a.s.1.) near the recent upper timberline located at 1800-2000 $\mathrm{m}$ a.s.1. (the white tent indicates the archaeological excavation) and toward the Karwendel mountain range in the Northern Limestone Alps (from Schäfer, 2011b).

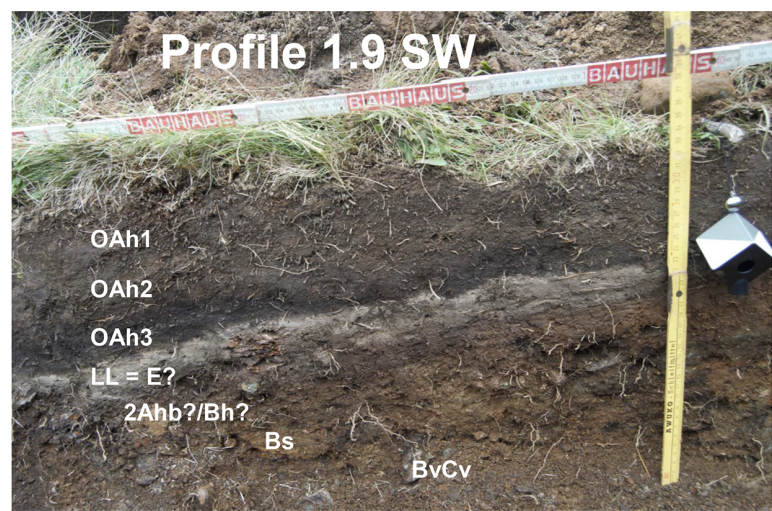

(a)

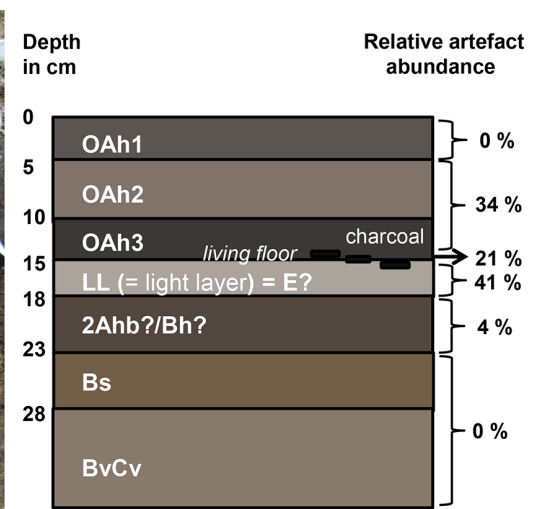

(b)

Figure 2. (a) Soil profile 1.9 SW on the Ullafelsen with the strikingly humus-enriched OAh3 and 2Ahb?/Bh? horizons. The latter was suggested by Geitner et al. (2011) to be a buried topsoil ( $\rightarrow$ 2Ahb) that was buried by aeolian deposition during and after the Younger Dryas. (b) Schematic horizontation of the soil profiles on the Ullafelsen; actually, the profiles reveal a high heterogeneity. The LL (light layer) reveals the highest relative artefact abundance, is overlain by several fire places on the Ullafelsen and is considered as the living floor of the Mesolithic hunter-gatherers. Please note that in previous publications (Geitner et al., 2011, 2014) the topsoil horizons were classified as Ah horizons. Due to TOC concentrations partly $\geq 15 \%$ we add the classification as O layers.

the southern part, mountain peaks (e.g. Villerspitzen) are of amphibolite (Nittel, 2011). During glacial times, the Fotsch Valley became $\mathrm{U}$-shaped by glacial erosive processes; the Ullafelsen at $1869 \mathrm{~m}$ a.s.l. $\left(47.14702^{\circ} \mathrm{N}, 11.21475^{\circ} \mathrm{E}\right)$ represents a rock hummock (Fig. 1). Several moraine walls at around $2000 \mathrm{~m}$ a.s.l. in the valley were assigned to the Egesen Stadial (Younger Dryas). The deposition of the innermost moraines during the early Preboreal around $11.0 \mathrm{kyr}$ ago is explicitly not excluded by Kerschner (2011) and might be explained with a glacier advance caused by pronounced humid conditions and a solar activity minimum during the "Preboreal Humid Phase" around 11.2 kyr BP (Hepp et al., 2019).
Nowadays, only a small glacier, the Fotscher Ferner, remains on the southernmost slopes of the valley.

Climatically, the Fotsch Valley is situated within the European west wind belt characterised by moderate climate and in a transition zone between the Northern and the Central Alps (Schlosser, 2011). The microclimate strongly depends on local conditions and orography with thermally and orographically induced wind systems being very regular.

The vertical vegetation gradients in the Fotsch Valley are similar to other parts of the Central Alps (Kemmer, 2011). Montane spruce forests with Picea abies dominance grow up to an elevation of $1600 \mathrm{~m}$ a.s.l. Above, it is replaced by 
the subalpine Arolla pine forest (Pinus cembra). While the potential timberline reaches up to $2200 \mathrm{~m}$ a.s.l., the actual timberline at $1800-2000 \mathrm{~m}$ a.s.l. is considered to have been lowered by anthropo-zoological disturbances associated with alpine pasturing. The study site Ullafelsen lies at the timberline and is characterised by the transition to (sub)alpine dwarf shrubs and pastures. Above $2300 \mathrm{~m}$ a.s.l., alpine grasslands (Nardus stricta, Caricion curvulae) and vegetation adapted to snow (Salicion herbaceae) dominate (Kemmer, 2011). Additionally, Alnus and Betula shrubs occur along creeks and Sphagnum and Carex peat bogs with associated respective vegetation developed especially in the (sub)alpine zone.

Leptosols and Cambisols are the dominant reference soil groups occurring in the alpine and the montane zone, respectively. In the subalpine zone, Podzols are frequently found especially under (sub)alpine dwarf shrub vegetation, and Histosols have developed in flatter valley floors and in slope positions. As emphasised in the introduction, the light layer LL on the Ullafelsen (see Fig. 2) reveals several characteristics that are untypical for Podzol $E$ horizons (Geitner et al., 2011, 2014). For instance, it is covered by an up to $15 \mathrm{~cm}$ thick OAh topsoil horizon, and the boundary between these units is often quite sharp. The LL is moreover considered as the Mesolithic living floor because in and on the LL most of the artefacts and fire places were found (Fig. 2). Geitner et al. $(2011,2014)$ suggested that the LL developed by aeolian dust deposition during and after the Younger Dryas (YD) and that it overlies a late glacial buried topsoil (2Ahb) that developed during the favourable climatic conditions of the Bølling-Allerød period. While unequivocal evidence for the existence of a late glacial 2Ahb horizon is hitherto missing, podzolisation processes alone can undoubtedly not explain the pedogenesis of the soil profiles on the Ullafelsen. Sedimentation processes are needed, too. The radiocarbondated fire places overlying the LL related to the presumed Mesolithic living floor serve as valuable chronological markers and date to the Preboreal and the Boreal periods from around 10.9 to $9.5 \mathrm{cal}$ kyr BP (re-calibrated from Schäfer, 2011b) (Table S1 in the Supplement). Last but not least, recent optically stimulated luminescence (OSL) dating of the LL yielding an age of $10.9 \pm 1.8 \mathrm{ka}$ corroborates - despite the large age uncertainties - this chronology and the idea of aeolian dust input during the late-glacial-Holocene transition (Michael Meyer, personal communication, University of Innsbruck, Austria, 2021).

\subsection{Sampling of modern vegetation and soil profiles}

In total, 20 leaf samples of typical and dominant vegetation types were collected from the Ullafelsen and surroundings in July 2015 and from the nearby Potsdamer Hütte peat bog (1970 m a.s.1.) and surroundings in August 2019. The sample set comprises coniferous trees ( $n=2$; Picea abies, Pinus cembra), Juniperus communis ( $n=1$; considered sepa- rate from coniferous trees), deciduous trees ( $n=2$; Betula pendula; Alnus viridis), alpine dwarf shrubs ( $n=4$, Vaccinium vitis-idaea, Vac. myrtillus, Calluna vulgaris, Rhododendron ferrugineum), herbs ( $n=5$; Potentilla erecta, Cardamine amara, Epilobium palustre, Saxifraga spec., Viola palustris), mosses ( $n=4$; Moss spec., Sphagnum rubellum, Sphag. cuspidatum, Amblystegiaceae) and grasses $(n=2$; not specified).

Four profile walls from the archaeological excavation (1.1 B5W, 1.1 B5S, 1.1 C4W and 1.1 G5N) and three profile walls from a nearby trench (1.9 NE, 1.9 NW and 1.9 SW) on the Ullafelsen (Fig. 3) were sampled by horizon in August 2017, resulting in 37 soil samples in total. Note that the schematic horizons as described in Fig. 2 are not fully developed in all profiles. The samples were classified by horizon, and only those samples that could be unambiguously assigned were used for the further data evaluation $(n=33)$ : OAh1 $(n=3)$, OAh2 $(n=3)$, OAh3 $(n=3)$, LL $(n=8)$, $2 \mathrm{Ahb}$ ?/Bh? $(n=6), \mathrm{Bs}(n=5)$ and $\mathrm{BvCv}(n=5)$. Moreover, a buried fire place was discovered several metres northeast of the excavation (RP20) (Fig. 3). There, three charcoal samples from 10, 15 and $20 \mathrm{~cm}$ depth were taken for radiocarbon dating.

In addition, 40 soil samples were taken from 13 profile walls elsewhere in the (sub-)alpine zone of the Fotsch Valley. Classification included $E(n=7)$ and $2 \mathrm{Ahb}$ ?/Bh? $(n=15)$ horizons; those samples serve as reference for the geoarchaeological samples from the Ullafelsen. Both $2 \mathrm{Ahb}$ and $\mathrm{Bh}$ horizons are to be expected in the study area due to podzolisation and slope dynamics. A detailed overview of all investigated profiles and samples including all results is provided in the Supplement (Table S2 and Fig. S1).

\subsection{Biogeochemical analyses and radiocarbon dating}

The soil samples were air dried, sieved $(<2 \mathrm{~mm})$ and finely ground. Total carbon (TC) and total nitrogen (N), as well as the stable carbon and nitrogen isotopic composition $\left(\delta^{13} \mathrm{C}\right.$ and $\delta^{15} \mathrm{~N}$, respectively), were determined using an elemental analyser coupled to an isotope ratio mass spectrometer (EA-IRMS). Given the non-carbonate parent rock material and the low $\mathrm{pH}$ values $\left(<4\right.$ in $\left.\mathrm{CaCl}_{2}\right)$ of the soils (Geitner et al., 2011), we consider in the following TC values to reflect total organic carbon (TOC). The natural abundances of ${ }^{13} \mathrm{C}$ and ${ }^{15} \mathrm{~N}$ are expressed in the usual $\delta$ scale; precision as determined by replication measurements of standards was $0.26 \%$ and $0.32 \%$, respectively.

Total lipid extracts from leaf and soil samples were obtained using Soxhlet and ultrasonic extraction following standard procedures (e.g. Lerch et al., 2018), and dichloromethane and methanol $(9: 1)$ were used as the solvent mixture. The aliphatic fraction including the $n$-alkanes was separated over aminopropyl pipette columns by eluting with hexane. The $n$-alkane identification and quantification were performed using a gas chromatograph-flame ionisa- 


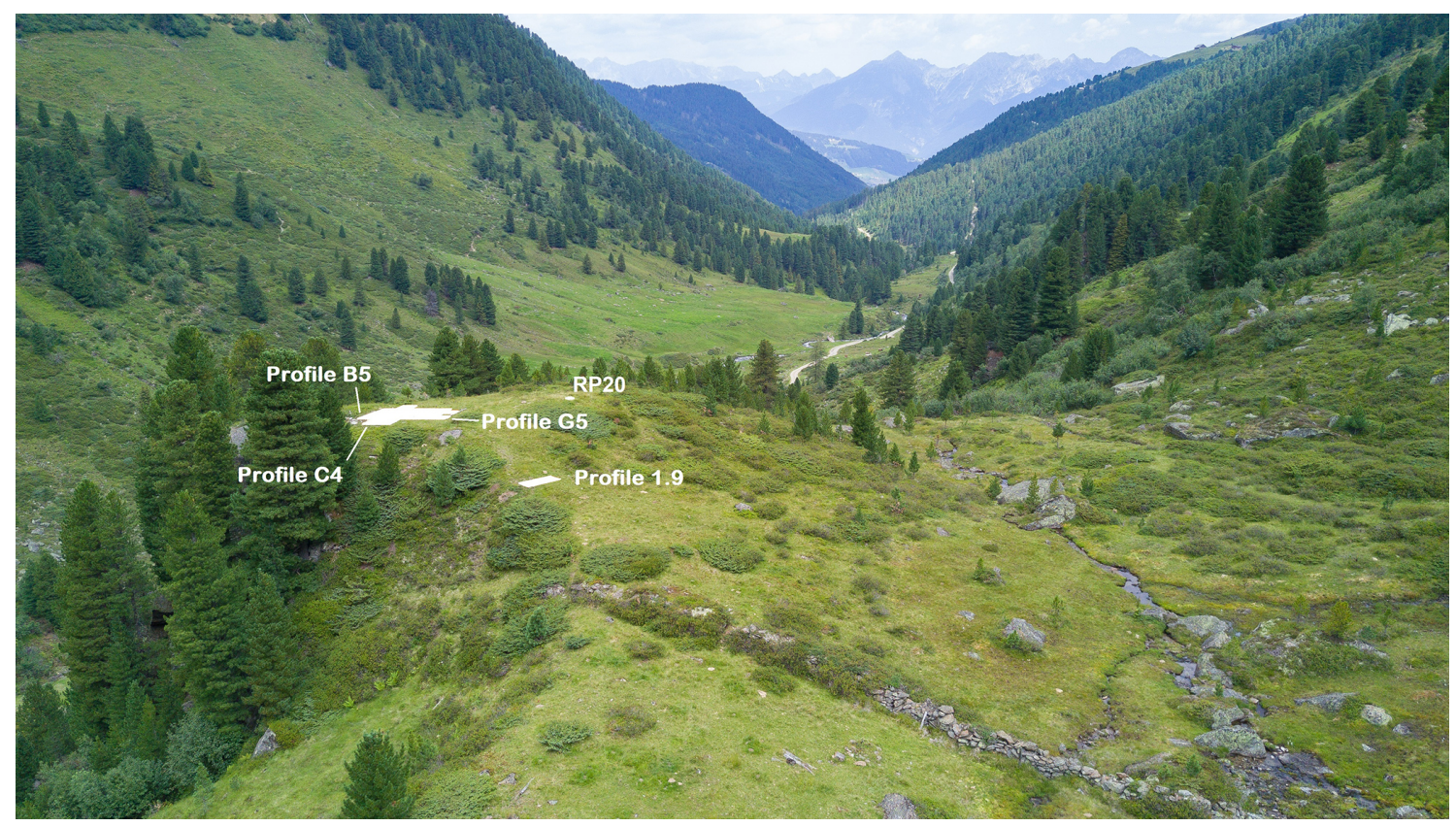

Figure 3. North-northwest view over the Ullafelsen at the upper timberline showing the geoachaeological excavation area 1.1 with the reopened and resampled profiles $1.1 \mathrm{~B} 5,1.1 \mathrm{C} 4$ and $1.1 \mathrm{G} 5$ and the newly opened and sampled profile, 1.9, several metres towards the southeast.

tion detector (GC-FID; GC-2010, Shimadzu) and external $n$ alkane standards. The total $n$-alkane contents (TACs) were calculated as the sum of $n \mathrm{C}_{21}$ to $n \mathrm{C}_{35}$ and are expressed in micrograms per gram $\left(\mu \mathrm{gg}^{-1}\right)$ for the leaf samples and additionally in micrograms per gram TOC for the soil samples. The cursive $n$ refers to unbranched and saturated hydrocarbon homologues; subscript numbers refer to the number of carbon atoms of the respective $n$-alkane homologues. For further data evaluation and interpretation, we additionally calculated the odd-over-even predominance (OEP) according to Eq. (1),

$\mathrm{OEP}=\frac{n \mathrm{C}_{27}+n \mathrm{C}_{29}+n \mathrm{C}_{31}+n \mathrm{C}_{33}}{n \mathrm{C}_{26}+n \mathrm{C}_{28}+n \mathrm{C}_{30}+n \mathrm{C}_{32}}$,

the average chain length (ACL) according to Eq. (2),

$\mathrm{ACL}=\frac{27 \times n \mathrm{C}_{27}+29 \times n \mathrm{C}_{29}+31 \times n \mathrm{C}_{31}+33 \times n \mathrm{C}_{33}}{n \mathrm{C}_{27}+n \mathrm{C}_{29}+n \mathrm{C}_{31}+n \mathrm{C}_{33}}$,

and an $n$-alkane ratio based on Schäfer et al. (2016) (Eq. 3):

n-Alkane ratio $=\frac{n \mathrm{C}_{31}+n \mathrm{C}_{33}}{n \mathrm{C}_{27}+n \mathrm{C}_{31}+n \mathrm{C}_{33}}$.

Black carbon (BC) was analysed using benzene polycarboxylic acids (BPCAs) as molecular fire markers following Glaser et al. (1998). In brief, hydrolysis was realised using $10 \mathrm{~mL}$ of $4 \mathrm{M}$ trifluoroacetic acid (TFA) for $4 \mathrm{~h}$ at $105^{\circ} \mathrm{C}$ (Brodowski et al., 2005). The residues were digested with $65 \%$ nitric acid for $7 \mathrm{~h}$ at $170^{\circ} \mathrm{C}, 100 \mu \mathrm{g}$ of phthalic acid were added as internal standard, and the filtrates were cleaned over Dowex 50W resin columns. After the addition of Biphenylen-2,2-dicarboxylic acid as recovery standard and after derivatisation, the BPCAs were detected and quantified using a GC-FID (GC-2010, Shimadzu) equipped with a $30 \mathrm{~m}$ SPB-5 column (Supelco) and an external standard mixture.

The results of the above-described analyses are depicted in the form of box plot diagrams in Figs. 4, 5 and 6. The box plots indicate the median (solid line between the boxes), the interquartile range (IQR) with the lower $(25 \%)$ and upper (75\%) quartiles, lowest values still within $1.5 \times$ IQR of the lower quartile, highest values still within the $1.5 \times$ IQR of the upper quartile, and outliers (dots).

Radiocarbon $\left({ }^{14} \mathrm{C}\right)$ dating at the Ullafelsen site was performed on four untreated soil samples and five soil samples that were pretreated with $\mathrm{HCl}$ and $\mathrm{H}_{2} \mathrm{O}_{2}$ from the $2 \mathrm{Ahb}$ ?/Bh? horizon, on seven bulk $n$-alkane samples from the LL, and on three charcoal samples from RP20 that were also pretreated with $\mathrm{HCl}$ (see Table 1). The $\mathrm{HCl}$ and $\mathrm{H}_{2} \mathrm{O}_{2}$ pretreatment aimed at removing young carbon pools in order to yield ages for old and resilient soil organic carbon pools reflecting the start of humus enrichment. The $\mathrm{H}_{2} \mathrm{O}_{2}$ pretreatment followed the method described by Favilli et al. (2009). Similarly, the ${ }^{14} \mathrm{C}$ dating of the bulk $n$-alkanes (following the method described by Zech et al., 2017 and Lerch et al., 2018) aimed at yielding maximum ages based on the insight that $n$-alkanes are not water-soluble and thus not rejuvenated by podzolisation processes. This is corroborated by extremely low concentrations of unsaturated hydrocarbons in dissolved organic 


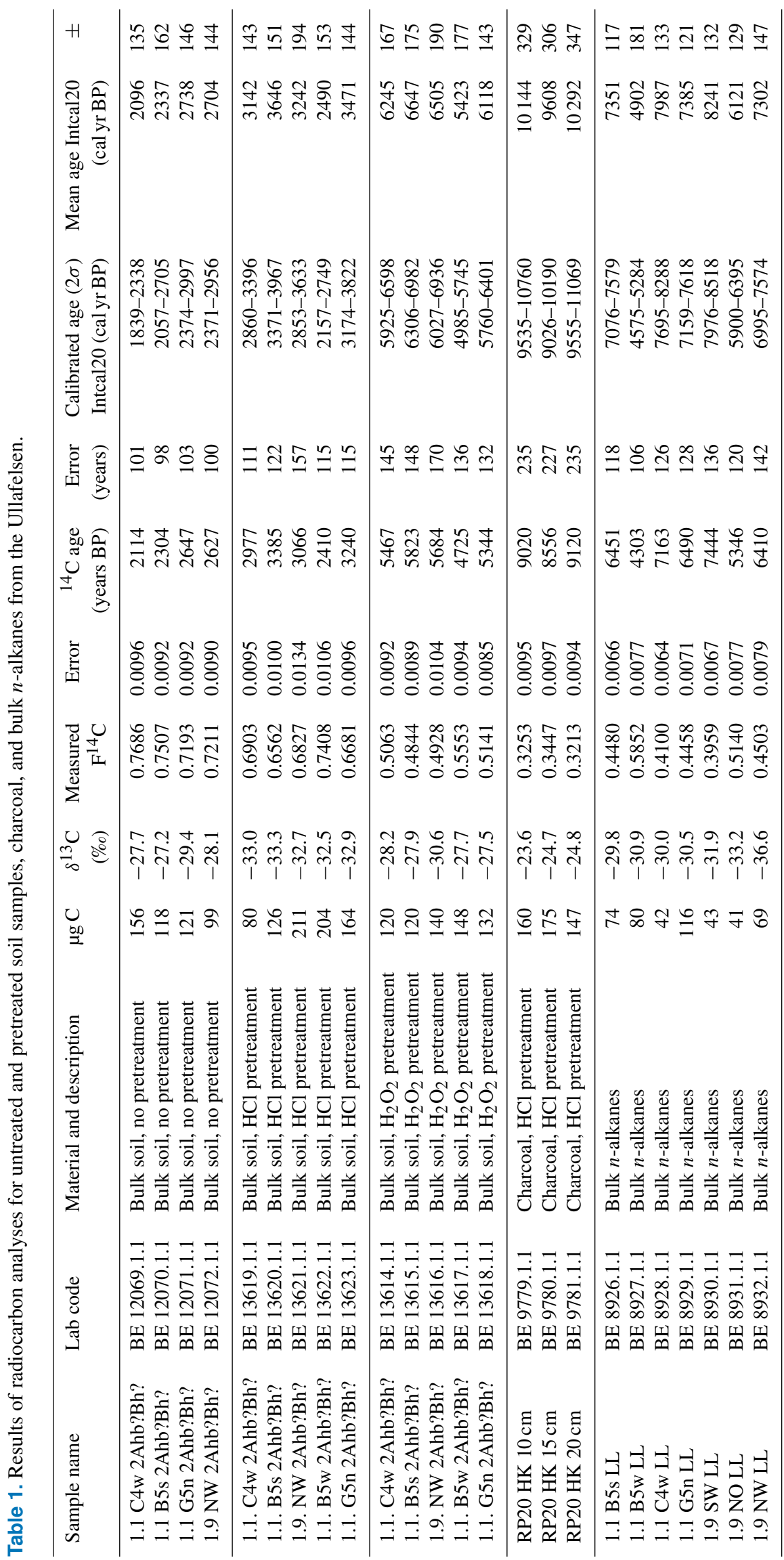


matter of Podzols as recently reported by Maria et al. (2019) based on high-resolution mass spectrometry.

Radiocarbon analyses were carried out at the Laboratory for the Analysis of Radiocarbon with accelerator mass spectrometry (LARA AMS) of the University of Bern, Switzerland (Szidat et al., 2014). Samples were packed and weighted into tin boats (Elementar, $6 \times 6 \times 12 \mathrm{~mm}$ ). The ${ }^{14} \mathrm{C}$ dating was performed on the Mini Carbon Dating System (MICADAS) AMS coupled online to an Elementar analyser (Wacker et al., 2010; Ruff et al., 2010). Results are reported as fraction modern $\left(\mathrm{F}^{14} \mathrm{C}\right)$, i.e. the activity ratio of a sample related to the modern level. All $\mathrm{F}^{14} \mathrm{C}$ results were corrected for cross-contamination and constant contamination according to the contamination drift model of Salazar et al. (2015). The ${ }^{14} \mathrm{C}$ ages were calibrated to calendar ages (cal yr BP) with the IntCal20 calibration curve (Reimer et al., 2020) using OxCal (Bronk Ramsey, 2009).

\section{Results and discussion}

\subsection{Total $n$-alkane contents and patterns of modern vegetation}

The total $n$-alkane contents (TACs) of the leaf samples range from 0 to $1819 \mathrm{\mu g} \mathrm{g}^{-1}$ (Picea abies and Betula pendula, respectively) (Fig. 4). This is within the range reported in the literature (Zech et al., 2012; Tarasov et al., 2013; Schäfer et al., 2016; Bliedtner et al., 2018; Trigui et al., 2019; Struck et al., 2020) and provides evidence that Betula, Alnus and many other deciduous trees produce high amounts of $n$-alkanes. By contrast, except for Juniperus, coniferous trees and mosses are characterised by very low TACs. This "blindness" of $n$ alkane biomarkers for coniferous trees needs to be considered when aiming at reconstructing vegetation history such as shifts of the upper timberline based on $n$-alkane patterns from soils and sediments.

Figure 4 moreover depicts the $n$-alkane patterns of deciduous trees being significantly different compared to other vegetation types. The ACL yielded a mean value of 27.4 for the two deciduous tree samples. For comparison, the mean ACL values for herbs, grasses and alpine dwarf shrubs are much higher, ranging from 29.9 to 30.4 . Similarly, the $\left(n \mathrm{C}_{31}+n \mathrm{C}_{33}\right) /\left(n \mathrm{C}_{27}+n \mathrm{C}_{31}+n \mathrm{C}_{33}\right)$ ratio of the deciduous tree samples is very low (0.06), whereas the mean $n$ alkane ratios of the other vegetation types are much higher (ranging from 0.63 to 0.95 ). This finding provides evidence that the chemotaxonomic differentiation between trees and shrubs versus grasses and herbs as suggested by, for example, Zech et al. (2009) needs regional calibration and/or validation (e.g. Schäfer et al., 2016; Bliedtner et al., 2018; Lemma et al., 2019; Trigui et al., 2019; Struck et al., 2020). In our Ullafelsen case study, the chemotaxonomic potential for reconstructing vegetation changes can be specified in terms of subalpine deciduous trees (Betula and Alnus) versus alpine grass, juniper and dwarf shrubland (including herbs), whereas the $n$-alkane biomarkers are "blind" for coniferous trees dominating the montane zone.

\subsection{TOC, TOC $/ \mathrm{N}, \delta^{13} \mathrm{C}, \delta^{15} \mathrm{~N}$ and BC contents of soil profiles on the Ullafelsen}

The TOC contents of the soil profiles on the Ullafelsen cover a wide range from $0.3 \%$ to $28.8 \%$ (Fig. 5). High TOC contents and stocks are indeed to be expected especially in subalpine soils near the timberline (Egli et al., 2006). Apart from high TOC values in the OAh1 horizon (ranging from $14.2 \%$ to $19.3 \%$ ), TOC maxima occur in the OAh3 and the 2Ahb?/Bh? horizons (Fig. 5). In fact, the two highest TOC values $(25.0 \%$ and $28.8 \%)$ of this dataset were measured for the OAh3 horizon of profiles $1.1 \mathrm{G} 5 \mathrm{~N}$ and $1.9 \mathrm{NW}$. This is in agreement with the OAh3 horizon on the Ullafelsen being often characterised by dark colours (indicating humus enrichment) and often containing charcoal particles (cf. Fig. 2). TOC maxima in the $2 \mathrm{Ahb}$ ?/Bh? horizon range from $4.8 \%$ to $8.3 \%$ and are expected both in the case of the burial of a former topsoil and in the case of podzolisation. Hence, the TOC results do not allow us to distinguish between these two options.

The TOC / $\mathrm{N}$ ratio on the Ullafelsen ranges from 12.4 to 37.2 (Fig. 5). Such high ratios also in the subsoils are typical for podzols (Zech et al., 2014) or charcoal-rich Anthrosols (Glaser et al., 2001; Glaser and Birk, 2012). Apart from the one outlier in the LL of profile 1.1 G5W (37.2), the highest TOC / $\mathrm{N}$ ratios are observed in the OAh3 horizon (ranging from 27.7 to 33.8). This again reflects geochemically that the OAh3 horizon overlies the LL as the Mesolithic living floor and often contains charcoal particles characterised by high TOC / $\mathrm{N}$ ratios (Fig. 2).

The $\delta^{13} \mathrm{C}$ values range from $-26.3 \%$ o to $-24.4 \%$ and are thus well within the range to be expected for soils under $\mathrm{C}_{3}$ vegetation (Glaser, 2005). Due to low $\mathrm{pH}$ values of our samples and the risk of $\delta^{13} \mathrm{C}$ biases (Brodie et al., 2011), we refrained from an $\mathrm{HCl}$ pretreatment prior to sample analyses. At the same time, carbonates are known to be ${ }^{13} \mathrm{C}$-enriched. Traces of dolomite were reported to occur sporadically especially in the LL and are considered residues of late glacial aeolian dust input (Geitner et al., 2011, 2014). Aeolian dust input is well known for the Northern Limestone Alps, too (Küfmann, 2003, 2008; Gild et al., 2018), and needs also to be considered as a process for the Middle and Late Holocene coverage of the Mesolithic living floor LL on the Ullafelsen. However, neither the LL nor the overlying horizons indicate a dolomite-induced ${ }^{13} \mathrm{C}$ enrichment. By contrast, the LL yielded the most negative $\delta^{13} \mathrm{C}$ values (Fig. 5). We suggest that this reflects the preferential removal of ${ }^{13} \mathrm{C}$-enriched and water-soluble soil organic carbon pools such as pectin, sugars and amino acids compared to ${ }^{13} \mathrm{C}$-depleted and waterinsoluble pools such as lignins and lipids (cf. Glaser, 2005) by podzolisation. 


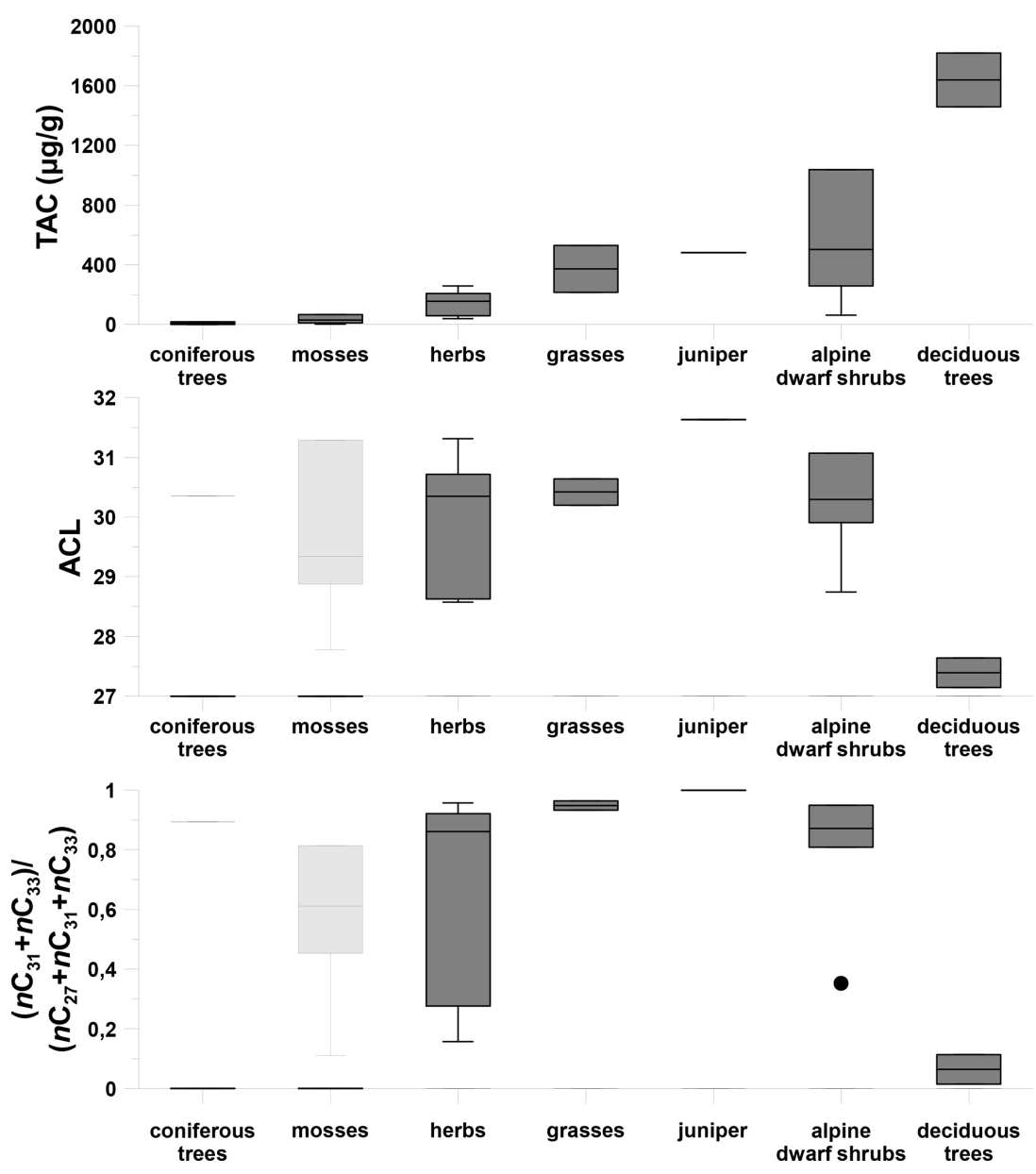

Figure 4. Total $n$-alkane content (TAC), average chain length (ACL) and $n$-alkane ratio $-\left(n \mathrm{C}_{31}+n \mathrm{C}_{33}\right) /\left(n \mathrm{C}_{27}+n \mathrm{C}_{31}+n \mathrm{C}_{33}\right)-$ of typical and dominant vegetation types on and around the Ullafelsen. Note that the very low TACs of coniferous trees (excluding juniper) and mosses (grey bar) hinder reconstructing respective vegetation changes using ACL and $n$-alkane ratios from soils.

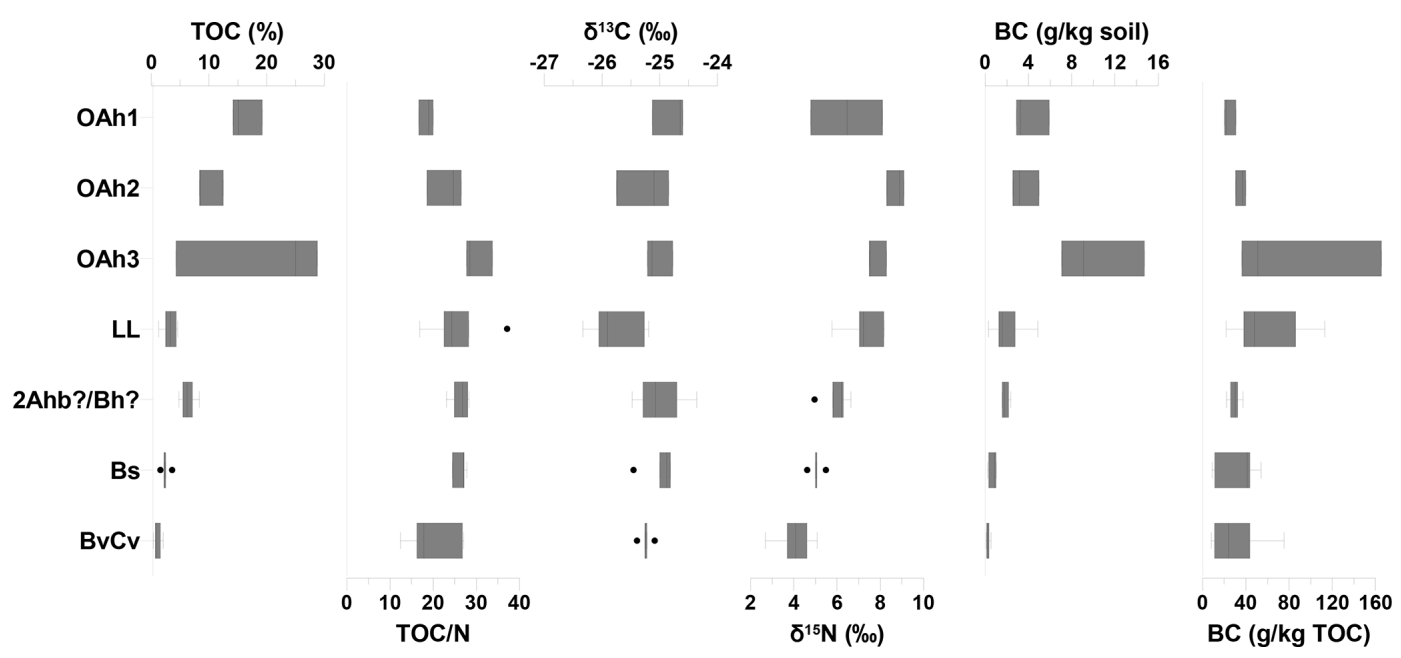

Figure 5. Box plots illustrating the total organic carbon content (TOC), the carbon to nitrogen ratio (TOC / N), the stable carbon isotopic composition $\delta^{13} \mathrm{C}$, the stable nitrogen isotopic composition $\delta^{15} \mathrm{~N}$ and the black carbon content (BC) in both grams per kilogram $\left(\mathrm{g} \mathrm{kg}^{-1}\right)$ soil and grams per kilogram TOC for the investigated soil profiles. 


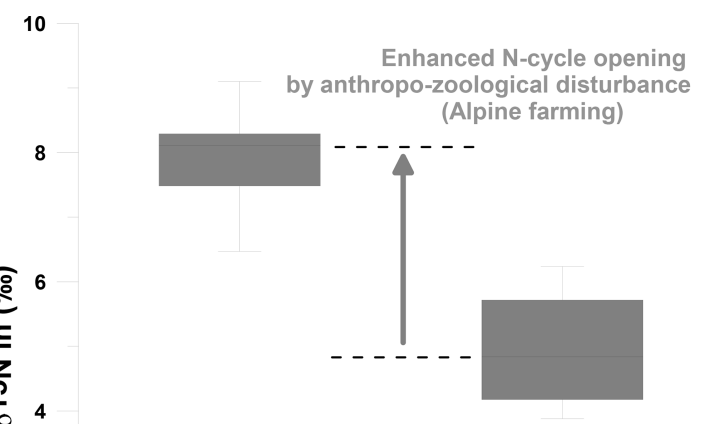

2

Figure 6. Box plots illustrating the comparison of the $\delta^{15} \mathrm{~N}$ results of the OAh1-3 horizons from the Ullafelsen versus the $\delta^{15} \mathrm{~N}$ results of the OAh horizons from the reference soil profiles.

Figure 5 moreover depicts the $\delta^{15} \mathrm{~N}$ values which range from $2.7 \%$ o to $9.1 \%$, with the upper part of the profiles being characterised by more positive values. Although shifts towards more positive $\delta$ values by degradation need to be considered both for $\delta^{13} \mathrm{C}$ and $\delta^{15} \mathrm{~N}$ values of soils and sediments (Zech et al., 2007), $\delta^{15} \mathrm{~N}$ is best described as an integrating indicator of the $\mathrm{N}$ cycle. Accordingly, ecosystem disturbances associated with the opening of the $\mathrm{N} \mathrm{cy-}$ cle result in more positive $\delta^{15} \mathrm{~N}$ values. For instance, Zech et al. (2011a) reported that intensively grazed pastures in the high-mountain areas of the eastern Pamirs are significantly ${ }^{15} \mathrm{~N}$-enriched by $3.5 \%$ compared to less exploited pastures. The high $\delta^{15} \mathrm{~N}$ values in the upper part of the Ullafelsen soil profiles therefore probably reflect the anthropo-zoological disturbance by Alpine farming (trampling and dung/urine by cows and sheep) since the Bronze Age (Haas et al., 2007; Pindur et al., 2007). On average, the OAh horizons from the Ullafelsen yield a $\delta^{15} \mathrm{~N}$ value of $7.7 \%$ compared to a $\delta^{15} \mathrm{~N}$ value of $4.6 \%$ for the OAh horizons of all reference soil profiles (Table S2 and Fig. 6). The $\delta^{15} \mathrm{~N}$ values of the LL are not statistically significantly more positive compared to the $E$ horizons of the reference soil profiles and thus do not provide any evidence for the human-induced disturbance during the Mesolithic.

The BC contents on the Ullafelsen reach up to $14.7 \mathrm{~g} \mathrm{~kg}^{-1}$ soil and $165.4 \mathrm{~g} \mathrm{~kg}^{-1}$ TOC (Fig. 5). For comparison, the famous and anthropogenically developed "Terra Preta" in the Amazonian Basin yielded similarly high BC contents of around $11 \pm 5 \mathrm{~g} \mathrm{~kg}^{-1}$ soil and around $200 \pm 30 \mathrm{~g} \mathrm{~kg}^{-1}$ TOC (Glaser et al., 2001). For the Nordic Dark Earth of Slavic settlements, Wiedner et al. (2015) reported BC contents of up

to $7.5 \mathrm{~g} \mathrm{~kg}^{-1}$ soil compared to a maximum $1.1 \mathrm{~g} \mathrm{~kg}^{-1}$ soil in reference soils. On the Ullafelsen, the OAh3 horizon reveals a distinct $\mathrm{BC}$ maximum (Fig. 5). When referring to grams per kilogram TOC, the LL also yielded higher BC contents than other horizons. This finding nicely reflects the field observations as documented during the (geo-)archaeological excavations that the fire places and the highest char particle abundance typically occur in or directly above the Mesolithic living floor LL. One might be surprised that the BC contents are not zero in the subsoil horizons $\mathrm{Bv}$ and $\mathrm{BvCv}$ where no char particles occur. However, BPCAs are not exclusive biomarkers for char. Humic and fulvic acids, as well as lignin-like structures, are compound classes typically dominating in dissolved organic matter of Podzols, and they are built up of (partly condensed) aromatic macromolecules, too. The latter, therefore, also produce BPCAs during the analytical BC analyses and are actually to be expected in subsoils of Podzols. Last but not least, we calculated the ratio of the individual BPCAs with five and six carboxylic groups (B5CA / B6CA) (Table 2). For the OAh3 horizon and the LL, where we argue that increased $\mathrm{BC}$ contents are fire-induced, we detected ratios of 0.65 and 0.60 , respectively. According to Wolf et al. (2013), ratios $<0.8$ are indicative of domestic fires, whereas ratios $>0.8$ are typical for forest ground or grass fires. The low B5CA / B6CA ratios hence provide evidence that the charcoal in and on the LL of the Ullafelsen is of human rather than natural origin.

\subsection{The $n$-alkane contents and patterns of soil profiles on the Ullafelsen}

The total $n$-alkane contents (TACs) in the OAh horizons range from 3 to $148 \mu \mathrm{g} \mathrm{g}^{-1}$ soil and from 61 to $648 \mu \mathrm{g} \mathrm{g}^{-1}$ TOC, respectively (Fig. 7). For comparison, the TACs of the OAh horizons of the reference soils range from 13 to $106 \mu \mathrm{g} \mathrm{g}^{-1}$ soil and from 238 to $635 \mu \mathrm{g} \mathrm{g}^{-1}$ TOC, respectively (cf. Table S2, data not illustrated). The OEP values range from 4.1 to 24.3 and are highest in the topmost OAh1 horizon (Fig. 7). This indicates fresh leaf wax input by plant litter on top and a certain degree of $n$-alkane degradation (cf. Zech et al., 2011c) in the deeper horizons. Both the TAC and the OEP values of the Ullafelsen are well within the range to be expected for very organic-rich mineral topsoils (Schäfer et al., 2016; Bliedtner et al., 2018; Lemma et al., 2019; Trigui et al., 2019; Struck et al., 2020).

Strikingly, the LL contains very low TACs, and no $n$ alkanes at all were detectable in most $2 \mathrm{Ahb}$ ?/Bh?, Bs and $\mathrm{BvCv}$ horizons (Fig. 7) despite partly strong modern root penetration occurring in these latter subsoil horizons (Geitner et al., 2011). This finding is in agreement with previous studies reporting that roots do not or at least only negligibly contribute to the $n$-alkane pools of subsoils and sediments (Zech et al., 2012; Häggi et al., 2014). Moreover, this finding undoubtedly rules out the assumption that the $2 \mathrm{Ahb} ? / \mathrm{Bh}$ ? horizon on the Ullafelsen could be a buried late glacial top- 
Table 2. Mean BPCA pattern (in \%) and B5CA / B6CA ratio of soil horizons on the Ullafelsen.

\begin{tabular}{lrrrrrrrrr}
\hline Horizon & B3CA & \pm & B4CA & \pm & B5CA & \pm & B6CA & \pm & B5CA / B6CA \\
\hline OAh1 $(n=3)$ & 8 & 3 & 31 & 5 & 27 & 4 & 34 & 4 & 0.80 \\
OAh2 $(n=3)$ & 8 & 2 & 28 & 4 & 28 & 1 & 36 & 5 & 0.79 \\
OAh3 $(n=3)^{1}$ & 6 & 1 & 23 & 1 & 28 & 4 & 43 & 4 & 0.65 \\
LL $(n=8)^{1}$ & 5 & 3 & 24 & 3 & 27 & 3 & 44 & 6 & 0.60 \\
2Ahb?/Bh? $(n=6)^{2}$ & 4 & 2 & 21 & 6 & 23 & 2 & 51 & 7 & 0.45 \\
Bs $(n=5)^{2}$ & 4 & 4 & 30 & 11 & 24 & 2 & 42 & 13 & 0.57 \\
BvCv $(n=5)^{2}$ & 2 & 5 & 47 & 35 & 27 & 20 & 23 & 32 & 1.17 \\
\hline
\end{tabular}

${ }^{1} \mathrm{BC}$ content maxima and the finding of char particles in the OAh3 horizon and the LL indicate that the respective BPCAs are primarily fire-derived. ${ }^{2}$ The absence of char particles and the identification of these horizons as Podzol subsoils suggest that the respective BPCAs are not fire-derived but primarily originate from translocated and adsorbed dissolved organic matter.

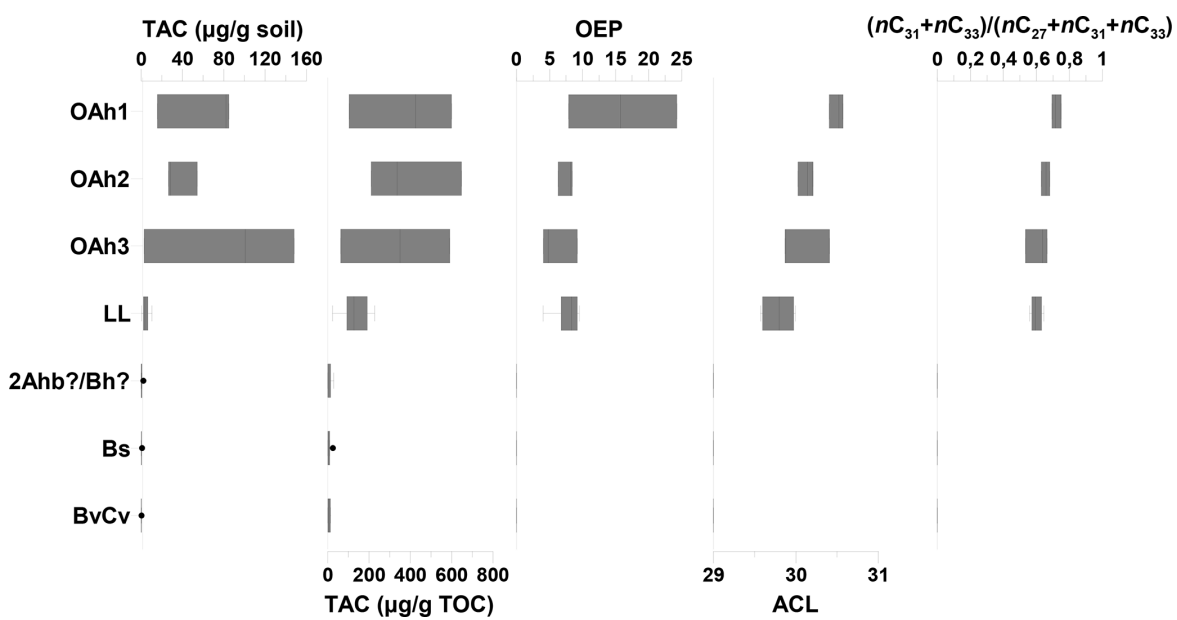

Figure 7. Box plots illustrating the total $n$-alkane content (TAC) in both micrograms per gram soil and micrograms per gram TOC, the odd-over-even predominance (OEP), the average change length (ACL), and the $n$-alkane ratio $\left(n \mathrm{C}_{31}+n \mathrm{C}_{33}\right) /\left(n \mathrm{C}_{27}+n \mathrm{C}_{31}+n \mathrm{C}_{33}\right)$ for the investigated soil profiles.

soil (2Ahb). In the latter case, leaf wax $n$-alkanes would have been deposited on and incorporated in this horizon. The humus accumulation of this horizon under discussion must therefore be attributed to other processes than leaf litter deposition, namely to organic matter translocation by podzolisation $(\rightarrow$ Bh horizon) and to a certain degree also to root input and rhizodeposition ${ }^{1}$.

For comparison, 15 horizons from the reference soil profiles were classified during fieldwork as $2 \mathrm{Ahb}, \mathrm{Bh}$ or $2 \mathrm{Ahb}$ ?/Bh? horizons. Figure 8 illustrates that the TACs for these samples yielded a bimodal histogram distribution. Either the samples yielded TACs of $>500 \mu \mathrm{gg}^{-1}$ TOC, revealing that these are indeed $2 \mathrm{Ahb}$ horizons, or they yielded TACs of mostly $<100 \mu \mathrm{g} \mathrm{g}^{-1}$ TOC, revealing that these are Bh horizons.

\footnotetext{
${ }^{1}$ Please note once again that $n$-alkanes are important constituents of leaf waxes and are hardly biosynthesised by roots. Moreover, $n$-alkanes are not water-soluble and thus not prone to translocation processes in soils (except for in particle-bound form by lessivation).
}

The ACL values from the Ullafelsen soil profiles range from 29.6 to 30.6 with a trend towards higher values from the LL to the OAh1 horizon (Fig. 7). Similarly, the $\left(n \mathrm{C}_{31}+n \mathrm{C}_{33}\right) /\left(n \mathrm{C}_{27}+n \mathrm{C}_{31}+n \mathrm{C}_{33}\right)$ ratio ranges from 0.53 to 0.75 and shows a slight increase from the LL to the OAh1 horizon, too. The ACL range thus corresponds well with the ACL values of the modern reference herbs, grasses and alpine dwarf shrubs with no indication of a significant contribution of deciduous trees (cf. Fig. 4). By contrast, the $\left(n \mathrm{C}_{31}+n \mathrm{C}_{33}\right) /\left(n \mathrm{C}_{27}+n \mathrm{C}_{31}+n \mathrm{C}_{33}\right)$ ratio of the soils is lower than the ratio yielded for the modern reference grasses and alpine dwarf shrubs; they fall within the range yielded for the modern reference herbs. On the one hand, we can certainly rule out a deciduous tree predominance on the Ullafelsen from these results. On the other hand, one may be tempted to reconstruct vegetation changes in terms of a herb predominance during the formation of the LL followed by an increasing grass and alpine shrub contribution towards the OAh1 horizon. However, we suggest caution against such a more in-depth vegetation reconstruction because $n$-alkane ra- 

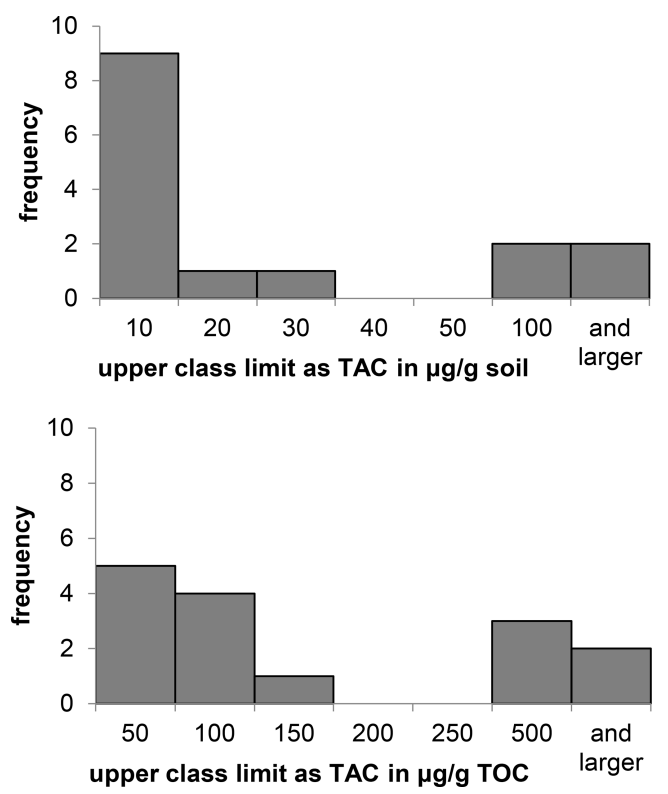

Figure 8. Histograms depicting the bimodal distribution of total $n$ alkane contents of $2 \mathrm{Ahb}$ ?/Bh? horizons from reference soil profiles in the Fotsch Valley.

tios are known to be affected by degradation (Zech et al., 2011c, 2012; Schäfer et al., 2016), and the above-presented OEP results clearly suggest that the $n$-alkanes in the OAh1 horizon are less degraded than the $n$-alkanes of the underlying horizons.

\subsection{Bulk, charcoal and $n$-alkane ${ }^{14} \mathrm{C}$ ages of soil profiles on the Ullafelsen}

Four bulk soil samples from the $2 \mathrm{Ahb}$ ?/Bh? horizon on the Ullafelsen were ${ }^{14} \mathrm{C}$ dated without any pretreatment. These analyses yielded calibrated ages ranging from $2.7 \pm 0.1$ to $2.1 \pm 0.1 \mathrm{cal}$ kyr BP (Table 1 and Fig. 9), which is much younger compared to the charcoals found in and above the $\mathrm{LL}$ and thus overlying the $2 \mathrm{Ahb}$ ?/Bh? horizon. According to Schäfer (2011b), the fire places date between 10.9 and $9.5 \mathrm{cal} \mathrm{kyr} \mathrm{BP}$, and the fire place RP20 discovered and dated within this follow-up study dates between $10.3 \pm 0.3$ and $9.6 \pm 0.3 \mathrm{cal}$ kyr BP (Table 1). This prominent ${ }^{14} \mathrm{C}$ age inversion has to be interpreted in terms of a strong rejuvenation of the bulk soil organic carbon in the 2Ahb?/Bh? horizon. Both modern root input and modern podzolisation need to be considered. Typically, podzolisation occurs in mineral soils covered by an acidic $\mathrm{O}$ layer rich in decomposing conifer needles or dwarf shrub litter. Although the Ullafelsen is nowadays grass-predominant, the up to $15 \mathrm{~cm}$ thick OAh horizon is characterised by very low $\mathrm{pH}$ values of 3.7 (Geitner et al., 2011) favouring podzolisation. In order to remove young carbon pools and thus to yield ages for old and resilient soil organic carbon pools reflecting the start of humus enrichment, we applied both $\mathrm{HCl}$ and $\mathrm{H}_{2} \mathrm{O}_{2}$ pretreat-

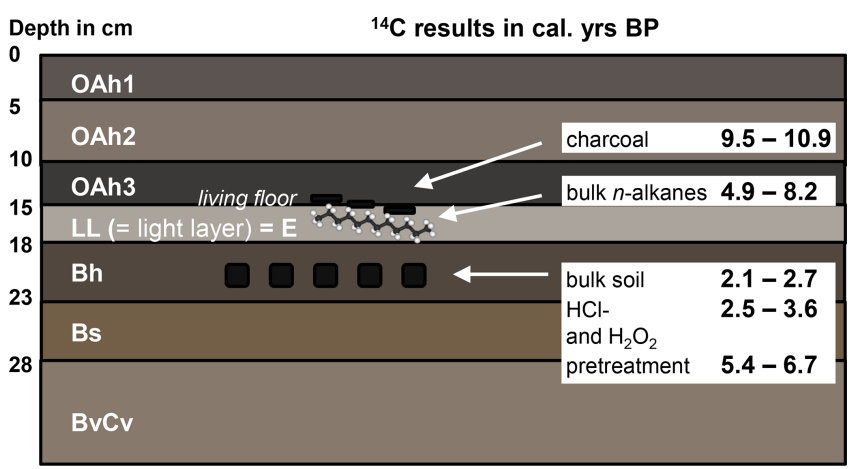

Figure 9. Results of radiocarbon analyses for untreated and pretreated soil samples, charcoal, and bulk $n$-alkanes from the U1lafelsen shown in stratigraphical position.

ment to five $2 \mathrm{Ahb}$ ?/Bh? samples. Accordingly, $\mathrm{HCl}$ pretreatment yielded calibrated ${ }^{14} \mathrm{C}$ ages ranging from $3.6 \pm 0.2$ to $2.5 \pm 0.2 \mathrm{cal}$ kyr BP, and $\mathrm{H}_{2} \mathrm{O}_{2}$ pretreatment (after Favilli et al., 2009) yielded calibrated ${ }^{14} \mathrm{C}$ ages ranging from $6.7 \pm 0.2$ to $5.4 \pm 0.2 \mathrm{cal} \mathrm{kyr} \mathrm{BP}$ (Table 1 and Fig. 9). Hence, radiocarbon dating does not provide evidence for a late glacial or an Early Holocene $2 \mathrm{Ahb}$ ?/Bh? formation pre-dating the Mesolithic living floor LL.

Last but not least, seven bulk $n$-alkane samples from the LL of soil profiles on the Ullafelsen yielded ${ }^{14} \mathrm{C}$ ages dating between $8.2 \pm 0.1$ and $4.9 \pm 0.2 \mathrm{cal} \mathrm{kyr} \mathrm{BP}$ (Table 1 and Fig. 9). This is younger than one might expect at first glance because the Mesolithic living floor LL was utilised from 10.9 to $9.5 \mathrm{cal} \mathrm{kyr} \mathrm{BP}$ according to the radiocarbon dating of the fire places. Given that a noteworthy post-depositional rejuvenation of $n$-alkane pools in subsoils by roots and aqueous translocation can be excluded (Zech et al., 2017; Lerch et al., 2018), this finding suggests that during and shortly after the Mesolithic occupation no vegetation prevailed on the Ullafelsen producing significant amounts of $n$-alkanes. As discussed in Sect. 3.1, most conifers produce no or negligible amounts of $n$-alkanes. A conifer-predominated vegetation cover on the Ullafelsen at $1869 \mathrm{~m}$ a.s.l. directly after the Mesolithic occupation is indeed to be expected according to timberline reconstructions in the region. For instance, Staffler et al. (2011) and Kutschera et al. (2014) reported that in the neighbouring Ötztal the timberline was at around $2450 \mathrm{~m}$ a.s.l. between $\sim 10$ to $5 \mathrm{cal}$ kyr BP. Subsequently, the timberline was depressed by several hundred metres due to an intensification of alpine pasturing. Similarly, the Neolithic presence of humans and their domestic livestock is documented for the Zillertal Alps from about $6.1 \mathrm{cal} \mathrm{kyr} \mathrm{BP}$ onwards (Haas et al., 2007; Pindur et al., 2007). We infer that on the Ullafelsen a noteworthy $n$-alkane production by grasses, herbs and dwarf shrubs predominating in the alpine pastures started only during the Neolithic or the Bronze Age. A more in-depth chronological assessment for the Fotsch Valley requires other environmental archives than the Ullafelsen soil 


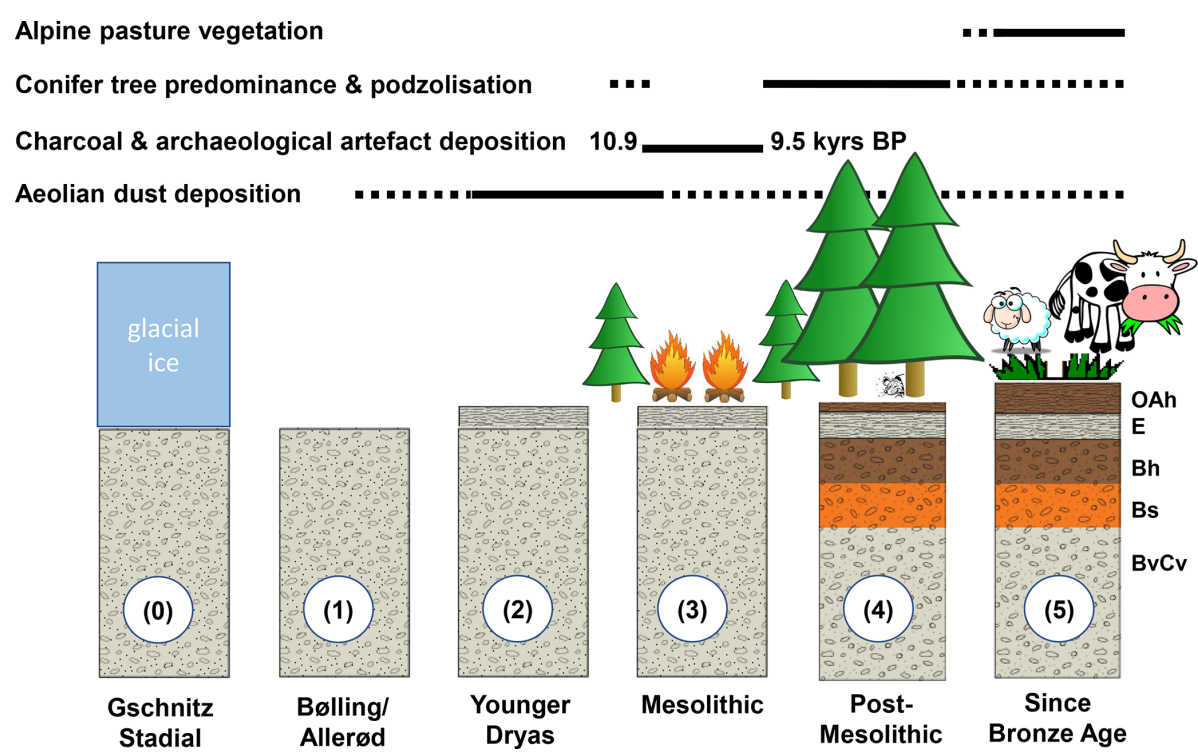

Figure 10. Didactically simplified revised scenario illustrating the hypothetical sequence of pedogenetic phases at the Ullafelsen (after Geitner et al., 2011, 2014).

profiles, such as peat bogs as high-resolution archives, and is a work in progress.

\section{Conclusions, synthesis and outlook}

Revisiting the Mesolithic site Ullafelsen in the Fotsch Valley with hitherto not applied biomarker, stable isotope and additional radiocarbon dating tools paid off. Based on our results and the discussion, the following conclusions can be drawn.

The total $n$-alkane content (TAC) was developed for the first time as an unambiguous proxy for distinguishing between buried (= fossil) 2Ahb topsoils and humus-enriched subsoils such as Bh horizons of podzols. Based on this proxy, we can rule out that the $2 \mathrm{Ahb}$ ?/Bh? horizon on the Ullafelsen is a buried topsoil. It developed by podzolisation as a Bh horizon below the LL and above a Bs horizon.

The LL is corroborated as the Mesolithic living floor and at the same time as an eluvial albic $E$ horizon. It is characterised by the most negative $\delta^{13} \mathrm{C}$ values of the soil profiles on the Ullafelsen. This can be attributed to the selective removal of water-soluble soil organic carbon pools by eluviation. The LL and the overlying OAh3 horizon yielded distinct fire-induced BC maxima, with B5CA / B6CA ratios pointing to human-induced fires rather than natural fires.

High $\delta^{15} \mathrm{~N}$ values in the LL and the overlying OAh horizons indicate anthropo-zoological disturbance and $\mathrm{N}$-cycle opening by alpine farming (trampling and dung/urine input). Given that a Mesolithic human disturbance cannot be inferred from these results, ongoing work focusses, amongst others, on human- versus herbivore-specific faecal sterol and bile acid biomarkers.
Leaf-wax-derived $n$-alkane biomarkers allow us to chemotaxonomically distinguish between subalpine deciduous trees $\left(n \mathrm{C}_{27}\right.$ predominance) versus (sub)alpine grasses, herbs and dwarf shrubs $\left(n \mathrm{C}_{29}, n \mathrm{C}_{31}\right.$ and/or $n \mathrm{C}_{33}$ predominance). Except for Juniperus, conifers produce no or extremely low $n$ alkane contents.

We caution against an in-depth vegetation reconstruction based on the rather small variability in $n$-alkane patterns on the Ullafelsen due to degradation effects. Yet, ${ }^{14} \mathrm{C}$ ages of bulk $n$-alkanes ranging from 8.2 to $4.9 \mathrm{cal} \mathrm{kyr} \mathrm{BP} \mathrm{com-}$ pared to Mesolithic charcoal ${ }^{14} \mathrm{C}$ ages ranging from 10.9 to $9.5 \mathrm{cal} \mathrm{kyr} \mathrm{BP}$ suggest that an $n$-alkane-producing vegetation cover (grasses, herbs or dwarf shrubs) did not start to predominate immediately after the Mesolithic abandonment. Instead, non- $n$-alkane-producing conifers should have dominated the vegetation cover, which is in agreement with timberline reconstructions for the Central Alps.

Our new data and insights into pedogenesis, human impact and landscape evolution from the Ullafelsen complement and partly revise previous studies and scenarios (Fig. 10). (1) While Geitner et al. (2011, 2014) suggested that the humus-rich horizon under the LL represents a late glacial buried topsoil, we did not find respective evidence either based on our leaf-wax-derived $n$-alkane analyses or based on our applied radiocarbon dating approaches. Similarly, no ${ }^{14} \mathrm{C}$ ages pre-dating the Holocene were obtained for basal samples of three peat bogs cored in the Fotsch Valley. (2) According to Geitner et al. $(2011,2014)$, aeolian dust deposition contributed to the build-up of the LL during the Younger Dryas and continued during the Holocene. This allowed the OAh horizons to build-up. (3) During the Mesolithic occupation, artefacts and charcoal were deposited on the LL. 
(4) However, we suggest in our revised scenario that the light-coloured feature of the LL developed primarily only after the Mesolithic abandonment, namely when conifer vegetation dominated the Ullafelsen from 9.5 cal kyr BP onwards and abundant conifer needle litter favoured podzolisation. Only during that period did the pronounced bleaching of the LL and thus the transformation of the LL into an $E$ horizon occur. Synchronously, the underlying Bh and Bs horizons started to develop. (5) A major human-induced vegetation change should have occurred with the onset and the intensification of alpine pasturing during the Neolithic and the Bronze Age. The low $\mathrm{pH}$ values $(<4)$ suggest that podzolisation still continues under the modern-day pasture vegetation predominated by grasses, herbs and dwarf shrubs.

Further follow-up studies in the Fotsch Valley focus on (i) the spatial distribution patterns of geochemical (TOC, TOC / N, P, Fe $)$ and isotope $\left(\delta^{15} \mathrm{~N}, \delta^{13} \mathrm{C}\right)$ patterns on the U1lafelsen, (ii) the identification of human- versus herbivorespecific faecal sterol and bile acid biomarkers, and (iii) investigating high-resolution peat archives.

Data availability. Data are available in the Supplement.

Supplement. The supplement related to this article is available online at: https://doi.org/10.5194/egqsj-70-171-2021-supplement.

Author contributions. MZ developed the project idea in collaboration with BG, DS and CG. Fieldwork was done by MZ, ML, JNH, DS and CG. ML carried out most of the laboratory work with contributions made by MZ, MB, TB, FS and GS. MZ prepared the manuscript, and all co-authors, including SöS and RZ, contributed to the discussion of the results and read and approved the manuscript.

Competing interests. The authors declare that they have no conflict of interest.

Disclaimer. Publisher's note: Copernicus Publications remains neutral with regard to jurisdictional claims in published maps and institutional affiliations.

Acknowledgements. We are very grateful to quite a number of students who supported our field and laboratory work within student projects and bachelor and master theses, namely Sabrina Andruch, Lilly Biedermann, Mikesch Blümlein, Larisa Boysen, Lukas Epp, Nina Feistmantl, Corinna Heinrich, David Horn, Tina Jahn, Martin Kaufhold, Marco Pacher, Tugba Ayla Schlegel, Katharina Schneider, Melissa Sehrt and Marika Stutzriemer. We also greatly acknowledge Sixten Bussemer and Jaroslaw Waroszewski for support of fieldwork and valuable discussions on pedogenesis, Ingrid Kögel-Knabner, Markus Steffens and Heike Knicker for valuable discussions on ${ }^{13} \mathrm{C}$-NMR, Jörg Löffler for valuable discussions on

${ }^{14} \mathrm{C}$ dating, Michael Meyer for communicating the OSL age obtained for the LL, Oliver Kiewert and his team from the Bergheim Fotsch for excellent food and accommodation, and last but not least Marianne Zech (formerly Benesch) and Heike Maennicke for support of lab work and their cheerful cohesion of our working group. We kindly thank Hans von Suchodoletz for his committed editorial handling and two anonymous reviewers for their constructive comments and suggestions.

Financial support. This research has been supported by the Deutsche Forschungsgemeinschaft (grant nos. ZE 844/12-1 and GL 327/23-1).

This open-access publication was funded by the Technische Universität Dresden (TUD).

Review statement. This paper was edited by Hans von Suchodoletz and reviewed by two anonymous referees.

\section{References}

Bliedtner, M., Schäfer, I. K., Zech, R., and von Suchodoletz, H.: Leaf wax $n$-alkanes in modern plants and topsoils from eastern Georgia (Caucasus) - implications for reconstructing regional paleovegetation, Biogeosciences, 15, 3927-3936, https://doi.org/10.5194/bg-15-3927-2018, 2018.

Bliedtner, M., von Suchodoletz, H., Schäfer, I., Welte, C., Salazar, G., Szidat, S., Haas, M., Dubois, N., and Zech, R.: Age and origin of leaf wax $n$-alkanes in fluvial sediment-paleosol sequences and implications for paleoenvironmental reconstructions, Hydrol. Earth Syst. Sci., 24, 2105-2120, https://doi.org/10.5194/hess-242105-2020, 2020.

Brodie, C. R., Leng, M. J., Casford, J. S. L., Kendrick, C. P., Lloyd, J. M., Yongqiang, Z., and Bird, M. I.: Evidence for bias in $\mathrm{C}$ and $\mathrm{N}$ concentrations and $\delta^{13} \mathrm{C}$ composition of terrestrial and aquatic organic materials due to preanalysis acid preparation methods, Chem. Geol., 282, 67-83, https://doi.org/10.1016/j.chemgeo.2011.01.007, 2011.

Brodowski, S., Rodionov, A., Haumaier, L., Glaser, B., and Amelung, W.: Revised black carbon assessment using benzene polycarboxylic acids, Org. Geochem., 36, 1299-1310, https://doi.org/10.1016/j.orggeochem.2005.03.011, 2005.

Bronk Ramsey, C.: Bayesian Analysis of Radiocarbon Dates, Radiocarbon, 51, 337-360, https://doi.org/10.1017/S0033822200033865, 2009.

Cornelissen, M. and Reitmaier, T.: Filling the gap: Recent Mesolithic discoveries in the central and south-eastern Swiss Alps, Quatern. Int., 423, 9-22, 2016.

Egli, M., Mirabella, A., Sartori, G., Zanelli, R., and Bischof, S.: Effect of north and south exposure on weathering rates and clay mineral formation in Alpine soils, Catena, 67, 155-174, 2006.

Egli, M., Mirabella, A., and Sartori, G.: The role of climate and vegetation in weathering and clay mineral formation in late Quaternary soils of the Swiss and Italian Alps, Geomorphology, 102, 307-324, 2008. 
Favilli, F., Egli, M., Brandova, D., Ivy-Ochs, S., Kubik, P., Maisch, M., Cherubini, P., and Haeberli, W.: Combination of numerical dating techniques using ${ }^{10} \mathrm{Be}$ in rock boulders and ${ }^{14} \mathrm{C}$ of resilient soil organic matter for reconstructing the chronology of glacial and periglacial processes in a high alpine catchment during the Late Pleistocene and Early Holocene, Radiocarbon, 51, 537-552, 2009.

Fontana, F., Visentin, D., and Wierer, U.: MesoLife. A Mesolithic perspective on Alpine and neighbouring territories, Quatern. Int., 423, 1-4, 2016.

Geitner, C., Bussemer, S., Ehrmann, O., Ikinger, A., Schäfer, D., Traidl, R., and Tscherko, D.: Bodenkundlich-stratigraphische Befunde am Ullafelsen im hinteren Fotschertal sowie ihre landschaftsgeschichtliche Interpretation, in: Das MesolithikumProjekt Ullafelsen (Teil 1). Mensch und Umwelt im Holozän Tirols 1, edited by: Schäfer, D., Philipp von Zabern, Innsbruck, Austria, 2011.

Geitner, C., Schäfer, D., Bertola, S., Bussemer, S., Heinrich, K., and Waroszewski, J.: Landscape archaeological results and discussion of Mesolithic research in the Fotsch valley (Tyrol), in: From the foreland to the Central Alps - Field trips to selected sites of Quaternary research in the Tyrolean and Bavarian Alps (DEUQUA EXCURSIONS), edited by: Kerschner, H., Krainer, K., and Spötl, C., Geozon, Berlin, Germany, 106-115, 2014.

Gild, C., Geitner, C., and Sanders, D.: Discovery of a landscapewide drape of late-glacial aeolian silt in the western Northern Calcareous Alps (Austria): First results and implications, Geomorphology, 301, 39-52, 2018.

Glaser, B.: Compound-specific stable-isotope $\left(\delta^{13} \mathrm{C}\right)$ analysis in soil science, J. Plant Nutr. Soil Sc., 168, 633-648, 2005.

Glaser, B. and Birk, J.: State of the scientific knowledge on properties and genesis of Anthropogenic Dark Earths in Central Amazonia (terra preta de Índio), Geochim. Cosmochim. Ac., 82, 39$51,2012$.

Glaser, B., Haumeier, L., Guggengerger, G., and Zech, W.: Black carbon in soils: the use of benzenecarboxylic acids as specific markers, Org. Geochem., 29, 811-819, 1998.

Glaser, B., Haumaier, L., Guggenberger, G., and Zech, W.: The "terra preta" phenomenon: a model for sustainable agriculture in the humid tropics, Naturwissenschaften, 88, 37-41, 2001.

Grillo, K., Dunne, J., Marshall, F., Prendergast, M., Casanova, E., Gidna, A., Janzen, A., Karega-Munene, Keute, J., Mabulla, A., Robertshaw, P., Gillard, T., Walton-Doyle, C., Whelton, H., Ryan, K., and Evershed, R.: Molecular and isotopic evidence for milk, meat, and plants in prehistoric eastern African herder food systems, P. Natl. Acad. Sci. USA, 117, 9793-9799, https://doi.org/10.1073/pnas.1920309117, 2020.

Haas, J. N., Walde, C., and Wild, V: Prähistorische Lawinen und ihr Einfluss auf die subalpinen Vegetation der Schwarzensteinalm im Zemmgrund (Zillertal, Tirol, Österreich), in: Nachweis und Analyse holozäner Lawinenereignisse in den Zillertaler Alpen, Österreich, Band 16, edited by: Luzian, R. and Pindur, P., Mitteilungen der Kommission für Quartärforschung, Vienna, Austria, 185-220, 2007.

Häggi, C., Zech, R., McIntyre, C., Zech, M., and Eglinton, T. I.: On the stratigraphic integrity of leaf-wax biomarkers in loess paleosols, Biogeosciences, 11, 2455-2463, https://doi.org/10.5194/bg-11-2455-2014, 2014.
Hepp, J., Wüthrich, L., Bromm, T., Bliedtner, M., Schäfer, I. K., Glaser, B., Rozanski, K., Sirocko, F., Zech, R., and Zech, M.: How dry was the Younger Dryas? Evidence from a coupled $\delta^{2} \mathrm{H}-$ $\delta^{18} \mathrm{O}$ biomarker paleohygrometer applied to the Gemündener Maar sediments, Western Eifel, Germany, Clim. Past, 15, 713733, https://doi.org/10.5194/cp-15-713-2019, 2019.

Kemmer, I.: Die rezente Vegetation im inneren Fotschertal / Nördliche Stubaier Alpen, in: Das Mesolithikum-Projekt Ullafelsen (Teil 1). Mensch und Umwelt im Holozän Tirols 1, edited by: Schäfer, D., Philipp von Zabern, Innsbruck, Austria, 2011.

Kerschner, H.: Spätglaziale Gletschervorstöße im Fotschertal, in: Das Mesolithikum-Projekt Ullafelsen (Teil 1). Mensch und Umwelt im Holozän Tirols 1, edited by: Schäfer, D., Philipp von Zabern, Innsbruck, Austria, 97-105, 2011.

Küfmann, C.: Soil types and eolian dust in high-mountainous karst of Northern Calcareous Alps (Zugspitzplatt, Wetterstein Mountains, Germany), Catena, 53, 211-227, 2003.

Küfmann, C.: Are Cambisols in alpine karst autochthonous or eolian in origin?, Arct. Antarct. Alp. Res., 40, 506-518, 2008.

Kutschera, W., Patzelt, G., Wild, E. M., Haas-Jettmar, B., Kofler, W., Lippert, A., Oeggl, K., Pak, E., Priller, A., Steier, P., Wahlmüller-Oeggl, N., and Zanesco, A.: Evidence for early human presence at high altitudes in the Ötztal Alps (Austria/Italy), Radiocarbon, 56, 923-947, 2014.

Lehndorff, E., Linstädter, J., Kehl, M., and Weniger, G.-C.: Fire history reconstruction from Black Carbon analysis in Holocene cave sediments at Ifri Oudadane, Northeastern Morocco, Holocene, 25, 398-402, 2015.

Lemma, B., Mekonnen, B., Glaser, B., Zech, W., Nemomissa, S., Bekele, T., Bittner, L., and Zech, M.: Chemotaxonomic patterns of vegetation and soils along altitudinal transects of the Bale Mountains, Ethiopia, and implications for paleovegetation reconstructions - Part II: lignin-derived phenols and leafwax-derived $n$-alkanes, E\&G Quaternary Sci. J., 68, 189-200, https://doi.org/10.5194/egqsj-68-189-2019, 2019.

Lerch, M., Bliedtner, M., Roettig, C.-B., Schmidt, J.-U., Szidat, S., Salazar, G., Zech, R., Glaser, B., Kleber, A., and Zech, M.: Lipid biomarkers in aeolian sediments under desert pavements - potential and first results from the Black Rock Desert, Utah, USA, and Fuerteventura, Canary Islands, Spain, E\&G Quaternary Sci. J., 66, 103-108, https://doi.org/10.5194/egqsj-66-103-2018, 2018.

Maria, E., Crancon, P., Lespes, G., and Bridoux, M.: Spatial variation in the molecular composition of dissolved organic matter from the Podzol soils of a temperate Pine Forest, ACS Earth and Space Chemistry, 3, 1685-1696, 2019.

Nittel, P.: Geologie, Hydrogeologie und Geomorphologie des Fotschertals - Kartierungsergebnisse Projekt "Sellrain" 2006, in: Das Mesolithikum-Projekt Ullafelsen (Teil 1). Mensch und Umwelt im Holozän Tirols 1, edited by: Schäfer, D., Philipp von Zabern, Innsbruck, Austria, 2011.

Pindur, P., Schäfer, D., and Luzian, R.: Nachweis einer bronzezeitlichen Feuerstelle bei der Schwarzensteinalm im Oberen Zemmgrund, Zillertaler Alpen, Mitt. Österr. Geogr. G., 149, 181-198, 2007.

Reimer, P. J., Austin, W. E. N., Bard, E., Bayliss, A., Blackwell, P. G., Bronk Ramsey, C., Butzin, M., Cheng, H., Edwards, R. L., Friedrich, M., Grootes, P. M., Guilderson, T. P., Hajdas, I., Heaton, T. J., Hogg, A. G., Hughen, K. A., Kromer, B., Manning, 
S. W., Muscheler, R., Palmer, J. G., Pearson, C., van der Plicht, J., Reimer, R. W., Richards, D. A., Scott, E. M., Southon, J. R., Turney, C. S. M., Wacker, L., Adolphi, F., Büntgen, U., Capano, M., Fahrni, S. M., Fogtmann-Schulz, A., Friedrich, R., Köhler, P., Kudsk, S., Miyake, F., Olsen, J., Reinig, F., Sakamoto, M., Sookdeo, A., and Talamo, S.: The IntCal20 Northern Hemisphere radiocarbon age calibration curve $(0-55 \mathrm{cal} \mathrm{kBP})$, Radiocarbon, 62, 725-757, https://doi.org/10.1017/RDC.2020.41, 2020.

Ruff, M., Fahrni, S., Gäggeler, H. W., Hajdas, I., Suter, M., Synal, H.-A., Szidat, S., and Wacker, L.: On-line Radiocarbon Measurements of Small Samples Using Elemental Analyzer and MICADAS Gas Ion Source, Radiocarbon, 52, 1645-1656, https://doi.org/10.1017/S003382220005637X, 2010.

Salazar, G., Zhang, Y. L., Agrios, K., and Szidat, S.: Development of a method for fast and automatic radiocarbon measurement of aerosol samples by online coupling of an elemental analyzer with a MICADAS AMS, Nucl. Instrum. Meth. B, 361, 163-167, https://doi.org/10.1016/j.nimb.2015.03.051, 2015.

Schäfer, D.: Das Mesolithikum-Projekt Ullafelsen (Teil 1). Mensch und Umwelt im Holozän Tirols (Band 1), Philipp von Zabern, Innsbruck, Austria, 560 pp., 2011a.

Schäfer, D. (Ed.): Das Mesolithikum-Projekt Ullafelsen - Landschaftlicher Rahmen und archäologische Befunde. Arbeitsstand 2009/2010, in: Das Mesolithikum-Projekt Ullafelsen (Teil 1). Mensch und Umwelt im Holozän Tirols 1, Philipp von Zabern, Innsbruck, Austria, 2011b.

Schäfer, I. K., Lanny, V., Franke, J., Eglinton, T. I., Zech, M., Vysloužilová, B., and Zech, R.: Leaf waxes in litter and topsoils along a European transect, SOIL, 2, 551-564, https://doi.org/10.5194/soil-2-551-2016, 2016.

Schlosser, E.: Das Fotschertal - regionale Klimatologie und gebirgsmeterologische Aspekte, in: Das Mesolithikum-Projekt Ullafelsen (Teil 1). Mensch und Umwelt im Holozän Tirols Band 1, edited by: Schäfer, D., Philipp von Zabern, Innsbruck, Austria, 2011.

Staffler, H., Nicolussi, K., and Patzelt, G.: Postglaziale Waldgrenzentwicklung in den Westtiroler Zentralalpen, Gredleriana, 11, 93-114, 2011.

Struck, J., Bliedtner, M., Strobel, P., Schumacher, J., Bazarradnaa, E., and Zech, R.: Leaf wax $n$-alkane patterns and compoundspecific $\delta^{13} \mathrm{C}$ of plants and topsoils from semi-arid and arid Mongolia, Biogeosciences, 17, 567-580, https://doi.org/10.5194/bg17-567-2020, 2020.

Szidat, S., Salazar, G. A. Vogel, E., Battaglia, M., Wacker, L., Synal, H.-A., Türler, A.: ${ }^{14} \mathrm{C}$ Analysis and Sample Preparation at the New Bern Laboratory for the Analysis of Radiocarbon with AMS (LARA), Radiocarbon, 56, 561-566, https://doi.org/10.2458/56.17457, 2014.

Tarasov, P., Müller, S., Zech, M., Andreeva, D., Diekmann, B., and Leipe, C.: Last glacial vegetation reconstructions in the extreme-continental eastern Asia: Potentials of pollen and $n$ alkane biomarker analyses, Quatern. Int., 290-291, 253-263, https://doi.org/10.1016/j.quaint.2012.04.007, 2013.

Trigui, Y., Wolf, Y., Sahakyan, L., Hovakimyan, H., Sahakyan, K., Zech, R., Fuchs, M., Wolpert, T., Zech, M., and Faust, D.: First calibration and application of leaf wax $n$-alkane biomarkers in loess-paleosol sequences and modern plants and soils in Armenia, Geosciences, 9, 263, https://doi.org/10.3390/geosciences9060263, 2019.
Wacker, L., Bonani, G., Friedrich, M., Hajdas, I., Kromer, B., Němec, M., Ruff, M., Suter, M., Synal, H.-A., and Vockenhuber, C.: MICADAS: Routine and HighPrecision Radiocarbon Dating, Radiocarbon, 52, 252-262, https://doi.org/10.1017/S0033822200045288, 2010.

Wiedner, K., Schneeweiß, J., Dippold, M., and Glaser, B.: Anthropogenic Dark Earth in Northern Germany - The Nordic Analogue to terra preta de Índio in Amazonia, Catena, 132, 114-125, 2015.

Wolf, M., Lehndorff, E., Wiesenberg, G., Stockhausen, M., Schwark, L., and Amelung, W.: Towards reconstruction of past fire regimes from geochemical analysis of charcoal, Org. Geochem., 55, 11-21, 2013.

Zech, M., Zech, R., and Glaser, B.: A 240,000-year stable carbon and nitrogen isotope record from a loess-like palaeosol sequence in the Tumara Valley, Northeast Siberia, Chem. Geol., 242, 307318, 2007.

Zech, M., Buggle B., Leiber, K., Marković, S., Glaser, B., Hambach, U., Huwe, B., Stevens, T., Sümegi, P., Wiesenberg, G., and Zöller, L.: Reconstructing Quaternary vegetation history in the Carpathian Basin, SE Europe, using $n$-alkane biomarkers as molecular fossils: problems and possible solutions, potential and limitations, Eiszeitalter und Gegenwart - Quaternary Sci. J., 58, 148-155, 2009.

Zech, M., Bimüller, C., Hemp, A., Samimi, C., Broesike, C., Hörold, C., and Zech, W.: Human and climate impact on ${ }^{15} \mathrm{~N}$ natural abundance of plants and soils in high mountain ecosystems - a short review and two examples from the Eastern Pamirs and Mt. Kilimanjaro, Isot. Environ. Healt. S., 47, 286-296, $2011 \mathrm{a}$.

Zech, M., Zech, R., Buggle, B., and Zöller, L.: Novel methodological approaches in loess research - interrogating biomarkers and compound-specific stable isotopes, E\&G Quaternary Sci. J., 60, 13, https://doi.org/10.3285/eg.60.1.12, 2011b.

Zech, M., Pedentchouk, N., Buggle, B., Leiber, K., Kalbitz, K., Markovic, S., and Glaser, B.: Effect of leaf litter degradation and seasonality on $\mathrm{D} / \mathrm{H}$ isotope ratios of $n$-alkane biomarkers, Geochim. Cosmochim. Ac., 75, 4917-4928, 2011c.

Zech, M., Rass, S., Buggle, B., Löscher, M., and Zöller, L.: Reconstruction of the late Quaternary paleoenvironment of the Nussloch loess paleosol sequence, Germany, using $n$-alkane biomarkers, Quaternary Res., 78, 326-335, 2012.

Zech, M., Kreutzer, S., Zech, R., Goslar, T., Meszner, S., McIntyre, C., Häggi, C., Eglinton, T., Faust D., and Fuchs, M.: Comparative ${ }^{14} \mathrm{C}$ and OSL dating of loess-paleosol sequences to evaluate postdepositional contamination of $n$-alkane biomarkers, Quaternary Res., 87, 180-189, 2017.

Zech, W. and Wilke, B.: Vorläufige Ergebnisse einer Bodenchronosequenzstudie im Zillertal, Mitteilungen der Deutschen Bodenkundlichen Gesellschaft, 25, 571-586, 1977.

Zech, W., Schad, P., and Hintermaier-Erhard, G.: Böden der Welt, Springer Spektrum Verlag, https://doi.org/10.1007/978-3-64236575-1, 2014. 